\title{
Socio-hydrology, politicization of water science and implication of the Eyes on Earth Study on the contemporary research dialogue in the Lancang-Mekong Basin
}

\author{
Richard Grünwald ${ }^{1}$, Wenling Wang ${ }^{1,2}$, Yan Feng ${ }^{3}$
}

$5 \quad{ }^{1}$ Institute of International River and Eco-Security/Asian International Rivers Center, Kunming, 650091, China

${ }^{2}$ Wuhan University China Institute of Boundary and Ocean Studies, 430072, Wuhan, China

${ }^{3}$ Yunnan Key Lab of International Rivers and Transboundary Eco-security, 650091, Kunming, China

Correspondence to: Richard Grünwald (grunwaldrichard@ynu.edu.cn), Wenling Wang (wangwl@ynu.edu.cn), Yan Feng (fengyan@ynu.edu.cn)

\section{Abstract.}

Since April 2020, the Eyes on Earth Study has received significant media attention for considering the Chinese mainstream reservoirs as one of the main drivers for changing the natural water flow and compounding the severe droughts in the LancangMekong Basin. Unlike other hydrological studies, the Eyes on Earth Study polarized the international research community and received unusual media attention. While the Eyes on Earth Study raised public awareness about upstream water operations and

15 motivated civil society to co-develop the water knowledge, there can be found numerous shortcomings and other irregularities in the current research dialogue over the research conclusions. By drawing on the politicization of scientific theories and combining the socio-hydrology with critical political ecology, the presented paper (1) conceptualizes the human-water interaction in the context of the politicization of the EoE Study, (2) reviews current development pathways in contemporary research dialogue in the Lancang-Mekong Basin, and (3) examines contemporary challenges for water science. To re-define the politicization of water science, the constructivist discourse analysis has been applied to investigate the argumentation patterns over the Eyes on Earth Study in the last 18 months (April 2020-September 2021). In addition, we applied the adapted Baker's model to double-check the content of the EoE Study and degree of alignment with high-quality research inputs. Our data show that (i) benefits from ensuring the standard research procedures outweigh the benefits from using the alternative research procedures, (ii) gradual stratification of contemporary research channels and simplification of research findings contribute to political distrust towards the water science, and (iii) growing intervention of non-traditional actors in the research dialogue produce the gap in applied discourse practices and medialize the desirable water narratives. The topic is highly actual and beneficial for water experts and other interdisciplinary scientists who want to better understand the power of hydrological studies and clarify the incentives undermining the trust in science. 


\section{Introduction}

30 To date, many scientists call for better transparency of the hydrological data, improved accuracy of the predictive models and bigger diversity of the research viewpoints (Morgan et al., 2018, Brown, 2015; Spruijt et al., 2014). However, science is not value-free (Pardini et al., 2021) and the growing demand for collaboration with non-scientists can be troublesome (Hamilton et al., 2019). Perhaps, the most interesting case of politicization of science can be traced to speculations over Chinese mainstream dams in the Lancang-Mekong Basin. Although many institutions and scientists analyse the actual impact of

35 hydropower dams on downstream countries (e.g. Binh et al., 2020; MRC, 2017; Hirsch, 2016; Biba, 2012; ICEM, 2010), numerous information gaps and sensitiveness of water issues (e.g. Mayeda and Boyd, 2020, Hamm et al. 2013) keep a plethora of water experts highly conservative to draw firm conclusions. This has changed in April 2020 when a team of two experts from the Eyes on Earth sparked a hot discussion about the actual impact of Chinese mainstream reservoirs (Basist and Williams, 2020a, SC, 2020b). To demonstrate the connection between upstream dams and alteration of the natural water flow, authors monitored the changes in the capacity of the Chinese water reservoirs in the last 28 years (1992-2019) and illustrated the negative consequences of the "missing water" at Chiang Saen gauge during the dry season (Basist and Williams, 2020a). Since then, the Eyes on Earth Study (EoE Study) has become a subject of countless interpretations (Grünwald, Feng and Wang, 2021). While many policy-makers praised the EoE Study as final proof of the negative impacts of Chinese mainstream dams (see Pompeo, 2020; Stilwell, 2020a; Stilwell, 2020b), many researchers warned against the simplification and misinterpretation

45 of the complex water factors (see MRC, 2020a; Kallio and Fallon 2020; Ketelsen, Sawdon and Räsären, 2020). On the other hand, the EoE Study has significantly increased public awareness and motivated US researchers to establish the Mekong Dam Monitor (MDM) operationalizing the EoE Study findings. The MDM has been launched in December 2020 under the auspices of the Mekong-U.S. Partnership (MUP), Stimson Center and other partners as an additional hydrological information platform advancing the existing regional water cooperation (SC, 2020a; Basist et al., 2020; Eyler et al., 2020a). Compared to other initiatives analysing the actual impact of Chinese mainstream dams on amplifying the water fluctuations (see Biba, 2016; Lu et al., 2014; Kummu and Varis, 2007), the EoE Study widely resonated in China-US official channels (e.g. Stilwell, 2020a; PRC-EUS, 2020; PRC-ECA, 2020), science-public forums (e.g. CSDS, 2021; EWC, 2021; FCCT, 2020) and foreign media (e.g. Eyler et al., 2020b, Tian, Liu and Lu, 2020; Niseyi, 2020; Van, 2020).

So far, many multi-stakeholders are determined to facilitate accountable research dialogue and speed up the research

55 investigations but very little has been made in advancing joint research collaboration with Chinese researchers and finding feasible solutions for downstream countries. To address these challenges, the presented paper (1) conceptualizes the humanwater interaction in the context of the politicization of the EoE Study, (2) reviews current development pathways in contemporary research dialogue in the Lancang-Mekong Basin, and (3) examines contemporary challenges for water science. The key novelty of this work is the re-conceptualization of the socio-hydrological approaches (e.g. Konar et al. 2018; Melsen,

60 Vos and Boelens, 2018; Srinivasan et al. 2016) by using the constructivist discourse analysis and using the adapted Baker's model to explore the research input quality of water science and degree of alignment with high-quality research inputs. 


\section{Theory and methodology}

\subsection{Socio-hydrology, politicization of science and research discourse}

Socio-hydrology presents a "new science" linking hydrology with socio-economic issues (Sivapalan, Savenije and Blöschl,

2012). In general, socio-hydrological studies mainly focus on understanding the dynamics of the co-evolution of the coupled human-water systems (Nüsser, 2017; Di Baldassarre et al., 2015; Elshafei et al., 2014; Di Baldassarre et al., 2013a; Di Baldassarre et al., 2013b) and exploring the causal relations, including the illogical behaviour and controversies among multistakeholders (e.g. Madani and Shafiee-Jood, 2020; Evers et al. 2017; Lane, 2014). Because most of the socio-hydrological studies use quantitative methods to grasp complex human-water connections and evaluate comprehensive water development trajectories via predictive mathematical models (Ghoreishi, Razavi and Elshorbagy, 2021; Gonzales and Ajami, 2017; Seidl and Barthel, 2017), some scholars began to study the conflict of ideas and values over transboundary water resources (Lu et al., 2021; Wei et al., 2020; Ert, Cohen-Amin and Dinar, 2019; Weber and Khademian, 2008). To date, there can be identified many water paradigms which have been produced upon the socially constructed assumptions (see Zeitoun et al., 2017; Earle, Jägerskog and Öjendal, 2010; Zeitoun and Mirumachi, 2008) and due to the inability to distillate the complex water knowledge for non-scientists (see Spruijt et al. 2014; Karr, 2006; McCreary, Gamman and Brooks, 2002). Although most of the solutions for dealing with the current water crisis were developed by natural scientists (Octavianti and Charles, 2019; Massuel et al., 2018; Lane, 2014), the research discourse requires more than technical answers to overcome these challenges (see Hamilton et al., 2019; Levy et al., 2016; Troy et al., 2015; Savenije, Hoekstra and van der Zaag 2014).

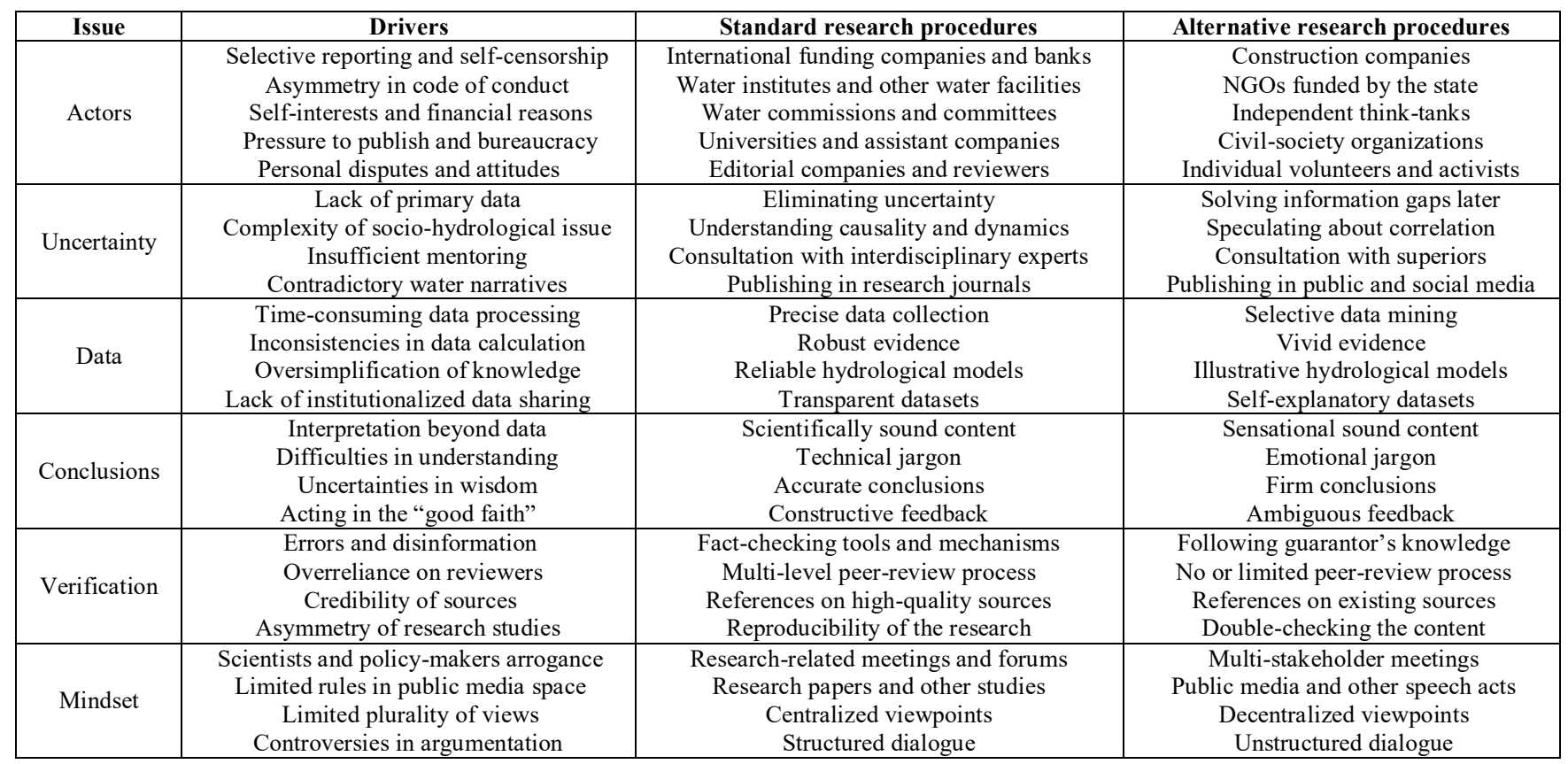

Table 1. General drivers of the politicization of science - comparison of the standard and alternative research procedures 
80 As the literature review of the drivers shown in Table 1, there are numerous aspects limiting the accountable research dialogue. From administrative obstacles (Young et al. 2014; Werner, 2015) and research biases (Kelly, Sadeghieh and Adeli, 2014; Ancker and Flanagin, 2007) to inconsistencies in research integrity (Morgan et al., 2018; Spruijt et al., 2014; Lupia, 2013; Sneddon and Fox, 2006) and changing research environment (Neff, 2020; Sarewitz, 2016). Standardly, it is the peer-review process that ensures the high-quality feedback on submitted research studies, verifies the robustness of research data and delimits the uncertainty from the research conclusions (Bohannon, 2013; Colquhoun, 2011). However, this is a very slow and subjective process that may eventually produce new research uncertainties (Brown, 2015; Dietz, 2013). Unlike the standard research journals possessing different research credibility, many publishers may not fact-check the research content and even accept controversial research papers with serious empirical shortcomings in exchange for mandatory publication fees (Vaikl, 2019; Martinson, 2017). Among other challenges belong the limited plurality of views on complex socio-hydrological issues (e.g. Yu et al. 2020; Roobavannan et al. 2018; Massuel et al. 2018), pressure on conceptualizing the causal relations in humanwater interaction (e.g. Madani and Shafiee-Jood, 2020; Evers et al. 2017; Lane, 2014), underdeveloped fact-checking tools (e.g. Vaccari and Cadwick, 2020; Lim 2018), censoring undesirable opinions (e.g. Kerckhove, Rennie and Cormier, 2015; Jansen and Martin 2015) and misinterpretation of science (e.g. Brown, 2015; Lupia, 2013; Pielke, 2004).

Another important factor presents moving the apolitical water issues into the public domain (Oosterloo, 2016; Buzan, Weaver and Wilde 1998). Once the politicization of science occurs either from the marginalization of the water challenges or inadequate political response (Atkins, 2019), it is highly difficult to depoliticize water science (Sarewitz, 2015). Normally, both scientists and policy-makers motivate multi-stakeholder to put more faith in "purely technical solutions" (Cuttita 2018; Jessop 2014) and re-consider their research mindset as well as other water stereotypes (Albrecht, 2021; Grünwald 2018) to ensure the accountable research dialogue. However, a plethora of conspiracy theories and other speculations seems to be highly

100 resilient (Cook, Ecker and Lewandowsky, 2015). Regardless of the nature of these research biases (see Kreps and Kriner, 2020; Lyengar and Massey, 2019; Petersen, Vincent and Westerling, 2019, Lorenz et al. 2013; van Laar, 2007) and applications of multifarious negotiation tools (Aspeitia, 2020; Fritz and Miller, 2018), the biggest challenge still represents the antiscientific approaches exacerbating the science communication by developing the research arguments beyond data (Morgan et al. 2018; Hmielowski et al. 2014, Rowlands et al., 2011) and without the robust evidence (Martin and MacDonald, 2020;

105 Bergner, 2010; Mutz, 1992). Such trend can be especially traced in the social and public media, and isolated stakeholder's research platforms with a limited plurality of the viewpoints (Post and Ramirez, 2018; Pielke 2004). Hence, while softening the complex research jargon, developing the research arguments in non-traditional research platforms and removing language barriers among stakeholders positively raise the public awareness and help to co-develop the water knowledge facing the realworld problems (Peters, 2013; Louhiala-Salminen and Kankaanranta, 2012; Baron, 2010; Karr, 2006), these platforms are

110 considered to have a higher chance for the overstatements (Mutz, 1992; Altheide and Snow, 1979) and supporting the content confirming the prior beliefs of the multi-stakeholders (Druckman, Fein and Leeper, 2012; Weingart, 2002). 


\subsection{Evaluation of the politicized water science}

By examining the strong asymmetry between various versions of the truth and clarifying the tendencies for rejecting other interpretations (Khan and MacEachen, 2021; Derrida 1997), we focus on multifarious viewpoints developing the EoE Study conclusions in official, public and social media (Morgan et al., 2018; Mutz, 1992). As the follow up for traditional sociohydrology movements enlarging new water challenges (e.g. Madani and Shafiee-Jood, 2020; Di Baldassarre et al., 2019), our perspective is closely related to the critical political ecology (Forsyth, 2012, 2004) and interpretive policy analysis (Yanow 2000) through which we study main approaches towards the EoE Study and formulate the epistemological dangers of using the "research shortcuts" in the Lancang-Mekong Basin research dialogue (see Sivapalan and Blöschl, 2015; Hajer 1995). Unlike the content analysis or the sentiment analysis focusing on the linguistic analysis of the public speech acts and other qualitative text analysis (see Wei et al., 2021; Ching, 2020), the constructivist discourse analysis focuses on the actions, perceptions and attitudes of the multi-stakeholders (Waitt, 2005). As some previous studies have shown (e.g. Fox and Sneddon, 2019; Gerlak and Schmeier, 2014), the discourse analysis proofed to be useful for uncovering the development pathways in transboundary water governance. Traditionally, it is the policy-makers who decide which water issues will be part of the national agenda (Buzan, Weaver and Wilde, 1998) and what scientific responses will be included in the official speech acts (Colloff, Grafton and Williams, 2021; Wester, Rap and Vargas, 2009; Weible, 2008). The scientific findings are predominantly used to support the existing political regime (Molle and Mollinga, 2009; Mollinga, 2008; Haas, 1992) and justify certain water practices (Lane, 2014, Latour, 2000, Sivapalan and Blöschl, 2015). In addition, the policy-makers are important in encompassing complex problems into the official state agenda, coordinating the innovative solutions among sectors, and mediating the conflict of interests among multi-stakeholders (Pardini et al., 2021; Cech, 2010; Pielke, 2007). On the other hand, it is usually the civil society that put pressure on policy-makers to re-consider their plans (Haefner, 2016; Matthews and Geheb, 2015; Mirumachi, 2015). A similar trend also occurred in terms of politicization of the EoE Study where civil society was often encouraged to participate in hydrological monitoring and promoting public awareness (SC, 2021a; EJN., 2021).

However, due to the knowledge gap and different viewpoints over the research process, many inputs from civil society may become highly unconstructive. From spreading rage comments and sharing misinformation on social media (e.g. PRC-ET, 2019, 2016) to sending insulting letters of concern (e.g. Corredor, 2017) and organizing various protests. Other politicization techniques may include using the non-scientific jargon, selective deleting of undesirable comments, making conclusions upon research abstracts, showing moral superiority or pretending the research objectivity by veiling the organization as a research platform (see MDM-F, 2021a, 2021b, 2020; MDM-T 2021a, 2020; S4M 2021a, 2021b). In contrast, the interdisciplinary researchers tend to address the scientific recommendations and get over their personal interests (Kasymov, 2011; Wade, 2004) to find innovative solutions for sustainable resources management (e.g. Jiménez et al. 2020; Houdret, Kramer and Carius, 2010). Therefore, whenever multi-stakeholders are developing their viewpoints, the accountable research dialogue should be built on mutual respect and standard research procedures (Colloff, Grafton and Williams, 2021; Pardini et al., 2021; Weber, Memon and Painter, 2011). 
To better understand the conflict of ideas among multi-stakeholders (Earle, Jägerskog and Öjendal, 2010; Swann and Bosson, 2008) and examine the quality of research inputs (Michalska-Smith and Allesina, 2017, Sarewitz, 2016), we adapted Baker's model (Baker, 2016) and outlined twelve key challenges in "standard research procedures" (see Table 2).

\begin{tabular}{|c|c|}
\hline Indicator & Note \\
\hline Selective reporting & Accuracy of results \\
\hline Pressure to publish & Nature of pressure and purpose of the study \\
\hline Quantitative analysis & Presence of verified statistical data \\
\hline Replicability & Successful applications and common traits \\
\hline Sufficient mentoring & Degree of consultation and inter-institutional collaboration \\
\hline Clear methodology & Objectives and limits correspond with the content of the study \\
\hline Experimental design & Degree of innovation and experimentation \\
\hline Transparent datasets & Available raw data for further review \\
\hline Fraud & Data manipulation to support desirable research conclusions \\
\hline Peer review process & Neutrality and sufficient number of reviewers \\
\hline Literature review & Complexity of references and publication dates \\
\hline Argumentation & Research channels and jargon used for developing the arguments \\
\hline
\end{tabular}

Table 2. Adapted Baker's model for indicating the quality of the water research inputs

150 Contradictory to Baker's view where the main factor demonstrating the credibility presents the actual content of the research study (Baker, 2016), we believe that the root of the problem lies in the outcome-oriented research process and different research mindsets of multi-stakeholders as other studies suggest (Bouleau, 2019; Petr et al., 2019; Bolsen and Druckman, 2015; Lorenz et al., 2013). Traditionally, when the research results are published, there are limited ways how to correct the controversial assessments (Haciyakupoglu et al., 2018; Lim, 2018). From getting further feedback through multifarious research channels (e.g. multi-stakeholder conferences, respond papers, public media) to personal communication with authors. Other alternatives present using various fact-checking tools and other third parties guaranteeing the quality of the research inputs (Moreno-Gil, Ramon and Rodríguez-Martínez, 2021; Pavleska et al., 2018). However, without adopting the code of conduct that will codify more responsibilities alongside the growing privileges for the non-state actors, the actual impact of non-scientists facilitating the contemporary research dialogue remains questionable. Hence, whenever authors use the "research shortcuts" to expand the audience and innovate the research process, interpretation beyond the data and other forms of legitimizing the prior beliefs without aligning with standard research procedures may negatively obscure the water science.

\subsection{Data}

To better understand the multi-stakeholder interaction, feedback and causal relations, we conducted an extensive literature review regarding the EoE Study and MDM between April 2020 and September 2021. As Table 3 and Figure 1 shown, the main attention was paid to the references on the EoE Study and MDM in primary and secondary sources. In addition, we also studied the broader political context, contemporary hydropolitical dynamics and MDM activities on the official social media websites (i.e. Twitter and Facebook). After that, we double-checked the data with the Lancang-Mekong Cooperation and Conflict Database (LMCCD) to enrich the list of recorded sources. At present, the LMCCD records over 3200 water-related events between six Mekong states (China, Myanmar, Thailand, Laos, Cambodia and Vietnam). The LMCCD is designed as a comprehensive water database visualizing the development pathways in various sectors and tracking the evolution of 
cooperation and conflict over the selected water issue. As some studies have previously shown (Grünwald, Feng and Wang, 2021; Grünwald, 2021; Grünwald, Wang and Feng, 2020; Grünwald, Feng and Wang, 2020), the LMCCD is not only beneficial for calculating the intensity of the cooperation and conflict events but also for filling the information gaps about multistakeholders inputs. Although the LMCCD lacks a full list of available sources (e.g. absence of micro-water events, duplicated articles, confidential materials and subjective unverifiable content), the LMCCD provides a substantial number of relevant sources suitable for conducting the constructivist discourse analysis and interpretative policy analysis.

\begin{tabular}{|c|c|}
\hline LMCCD requirements & Keyword Search \\
\hline Must include the following keywords: & Eyes on Earth Study, Mekong Dam Monitor \\
\hline Include at least one downstream country: & Myanmar, Thailand, Cambodia, Laos, Vietnam \\
\hline May include indirect references: & $\begin{array}{l}\text { "manipulation of data", "manipulation of the water flow", "the US Study claims", "new study } \\
\text { found", "wetness index", "water data transparency", "natural water flow", "the Study" }\end{array}$ \\
\hline Exclude duplicate and irrelevant sources if: & $\begin{array}{l}\text { more than } 50 \% \text { of the content is copied, author, name and publication date of the article is changed, } \\
\text { the content could not be verified by cross-references, the content is not intended for publication }\end{array}$ \\
\hline
\end{tabular}

Table 3. Searching criteria for literature review

\begin{tabular}{c|c|c|c|c|c|c|c|} 
Step 1 \\
Data collection
\end{tabular}

180 Figure 1. Outline of the data collection process

\section{Results}

\subsection{Approaches towards the Eyes on Earth Study}

By drawing on 1020 literature sources in the last 18 months, we outlined the approaches towards the EoE Study findings (Table 4). These approaches have been divided into two main groups and several sub-groups to grasp the nuances between the official

185 (i.e. policy-makers and supreme state representatives), semi-official (i.e. scientists and interdisciplinary water experts) and unofficial rhetoric (i.e. civil society and other non-state actors). For better clarification of key arguments and reflecting different water-knowledge gaps among different actors, the text compares the key stakeholders, drivers, expected outcomes and expected impacts of the EoE Study on the transboundary water governance. References on non-Mekong issues (e.g. the ChinaUS trade war, coronavirus pandemic (COVID-19), territorial disputes over the Himalayan region) and other speculations with unclear evidence have been significantly reduced to ensure information unity. 


\begin{tabular}{|c|c|c|c|c|}
\hline Approach & Stakeholders & $\begin{array}{ll}\text { Drivers } \\
\end{array}$ & Expected outcomes & Expected impact \\
\hline \multirow{3}{*}{ 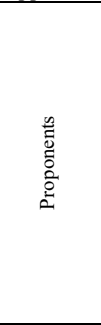 } & $\begin{array}{l}\text { US officials } \\
\text { Thailand officials* } \\
\text { Vietnam officials* }\end{array}$ & $\begin{array}{l}\text { + Address negatives impacts of Chinese dams } \\
\text { + Ensure better transparency of hydrological data } \\
\text { + Advance regional water cooperation via MUP } \\
\text { + Stop China's aggressive bullying actions }\end{array}$ & $\begin{array}{l}\text { + Support long-term concerns over river flow } \\
\text { + Provide reasonable facts to draw firm conclusions } \\
\text { + Verify manipulation of water flow by US scientists } \\
\text { + Highlight prolonged severe droughts in recent years }\end{array}$ & $\begin{array}{l}\text { + Operationalize data via the MDM } \\
\text { + Promote hydrological data monitoring } \\
\text { + Motivate MRC to become part of the FLM } \\
\text { + Enhance cooperation with foreign donors }\end{array}$ \\
\hline & $\begin{array}{l}\text { MUP/FLM/MDM } \\
\text { Stimson Center } \\
\text { Eyes on Earth } \\
\text { Other researchers } \\
\end{array}$ & $\begin{array}{l}\text { + Fill the information gaps about upstream dams } \\
\text { + Understand "missing water" at Chiang Saen } \\
\text { + Examine the link between droughts and dams } \\
\text { + Test replicability of the wetness index } \\
\end{array}$ & $\begin{array}{l}\text { + Upstream dams compound severe droughts } \\
+ \text { Other environmental cumulative effects are marginal } \\
\text { + Upstream dams significantly affect water flow } \\
\text { + Re-iterate that further investigations are needed }\end{array}$ & $\begin{array}{l}\text { + Put pressure on LMCWIP timely notification } \\
\text { + Provide better water information by MDM } \\
\text { + Facilitate public-research dialogue via MUP } \\
\text { + Justify the arguments in public media }\end{array}$ \\
\hline & $\begin{array}{l}\text { NGOs }^{* 1} \\
\text { Foreign media } \\
\text { Civil society } \\
\text { Other }\end{array}$ & $\begin{array}{l}\text { + Secure downstream countries from China } \\
\text { + Escalation of US-China rivalry } \\
\text { + Comparison with territorial disputes in Asia } \\
\text { + End up the speculations about Chinese dams }\end{array}$ & $\begin{array}{l}\text { + Show irrefutable research findings by US scientists } \\
\text { + Provide a plausible explanation of water changes } \\
\text { + Make undeniable proof of China's ulterior motives } \\
\text { + Use as a tool for enforcing communication with China }\end{array}$ & $\begin{array}{l}\text { + Demonize China's upstream operations } \\
\text { + Add research findings in a non-water context } \\
\text { + Simplify the environmental complexities } \\
\text { + Marginalize critics of the EoE Study }\end{array}$ \\
\hline \multirow{3}{*}{ 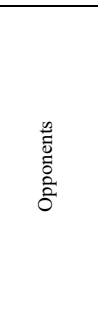 } & PRC officials & \multirow{3}{*}{$\begin{array}{l}\text { + No reason to pay attention to biased study } \\
\text { + Worry about sabotaging regional cooperation } \\
\text { + Unacknowledged China's cooperation pathways } \\
\text { + Need to address rumors by scientific means } \\
\text { + Lack of accountable research dialogue } \\
\text { + Slow advancements in water research } \\
\text { + Growing politicization of water science } \\
\text { + Impatience with lack of systemic solutions } \\
\text { + Justify the establishment of MUP } \\
\text { + MRC does not support EoE Study conclusions } \\
\text { + LMC-MUP contestation in Southeast Asia } \\
\text { + Exaggerate the real impact of Chinese dams }\end{array}$} & \multirow{3}{*}{$\begin{array}{l}\text { + Concern about groundless report countering the facts } \\
\text { + MRC already made their science-based assessment } \\
\text { + Emphasize that China suffered from droughts too } \\
\text { + Ensure that China guarantees reasonable discharge } \\
\text { + Hydro-meteorological conditions affect river flow } \\
\text { + Chinese mainstream dams may not amplify droughts } \\
\text { + Concern about the misinterpretation of EoE Study } \\
\text { + Provide suggestions for improving the EoE Study } \\
\text { + Question the accuracy of the EoE Study findings } \\
\text { + Raise doubts about objectivity due to the US funding } \\
\text { + Warn against irregularities and technical shortcomings } \\
\text { + Emphasize China's achievements in water cooperation }\end{array}$} & \multirow{3}{*}{$\begin{array}{l}\text { + Recommend to quote EoE Study with caution } \\
\text { + Support research-policy meetings } \\
\text { + Facilitate intergovernmental cooperation } \\
\text { + Enhance joint research investigations } \\
\text { + Advance LMC water cooperation } \\
\text { + Revise the LMWCIP agenda } \\
\text { + Explore environmental cumulative effects } \\
\text { + Call for more international research debates } \\
\text { + Encourage PRC scientists to do more research } \\
\text { + Stress the reliance on international scientists } \\
\text { + Motivate LMC to minimize data inconsistency } \\
\text { + Stimulate LMWCIP to better communicate }\end{array}$} \\
\hline & $\begin{array}{c}\text { PRC scientists* } \\
\text { LMC/LMWCIP* } \\
\text { MRC* } \\
\text { Other researchers }\end{array}$ & & & \\
\hline & $\begin{array}{l}\text { PRC media } \\
\text { Civil society } \\
\text { Other }\end{array}$ & & & \\
\hline
\end{tabular}

* Indicates general inclination rather than the official stance of multi-stakeholders

${ }^{1}$ Mainly environmental NGOs, including Scientists for the Mekong, Save the Mekong, International Rivers, etc.

${ }^{2}$ Mainly international public media (e.g. Reuters, The Diplomat) and regional public media (e.g. Bangkok Post, Vietnam+).

${ }^{3}$ Mainly Chinese state media (e.g. Xinhua) and public media (e.g. South China Morning Post, Global Times, CGTN).

Table 4. Summary of mainstream approaches towards Eyes on Earth Study.

The results show that there is a stark contrast between proponents and opponents of the EoE Study. For proponents, the EoE Study conclusions present "new evidence" supporting the long-term concerns about the actual impact of Chinese mainstream dams. These conclusions have mainly circulated in official channels (e.g. LKY, 2020; Pompeo, 2020; Stilwell, 2020a, 2020b) and public media (Grünwald, Feng and Wang, 2021). However, since the proponents of the EoE Study predominantly focus on the negative effects of Chinese mainstream dams on the natural water flow and other non-water related security concerns, the debates about the solutions for downstream countries remains vague. To date, the popularity of the EoE Study conclusions is mainly driven by US research discourse, long-term preconceptions, particularly towards the Chinese actions and upstream multipurpose water projects (Grünwald, 2021, 2020, 2018). Other reasons for growing awareness of the EoE Study present high medialization (Van, 2020; Niseyi, 2020; Eyler, 2020; Eyler et al. 2020b), simplified research jargon (e.g. Eyler and Weatherby, 2020; EWC, 2021) and frequent interventions of the EoE Study proponents in science-public meetings (e.g. Keshap, 2021; SC, 2021a).

For opponents, the EoE Study conclusions widely resonated in Chinese official (e.g. MOFA PRC, 2020a, 2020b; PRC-EUS, 2020; SCPRC, 2020; PRC-ECA, 2020) and public media (Grünwald, 2021). So far, the opponents mainly speculated about the ulterior motives of the EoE Study authors, the geopolitical context of US-China rivalry and other sources of prejudice against Chinese actions (see Grünwald, Feng and Wang, 2021). Most of the attempts refuting the EoE Study were driven by highlighting China's positive advancements in regional water cooperation (e.g. LMWCIP, 2021a; MOFA PRC, 2020c) and raising the concerns about the objectivity of research that overlook the scientific responses (MRC, 2020b; Kallio and Fallon, 2020; Ketelsen, Sawdon and Räsärenen, 2020). Special attention from opponents of the EoE Study has been paid to 
advancements in hydrological data sharing through the Lancang-Mekong Cooperation Water Information Platform (LMCWIP) established in November 2020 (MOFA PRC, 2020a) and China's research study re-examining the actual impacts of Chinese mainstream dams on the river (Tian et al., 2020). Although the unofficial response from Tsinghua University presents an important step for facilitating the research dialogue without confronting the EoE Study findings (Kallio, Räsären and Ketelsen 2020; Kallio, 2020), the research study was published outside of the traditional research channels and have not provided robust evidence for showing the positive effects of Chinese mainstream dams on the river (see Han, Mea and An, 2021; MRC, 2019c; Wang et al., 2017). A similar problem can be also found in terms of the LMWCIP which due to the communication shortcomings of the LMCWIP (LMWCIP, 2021b) and the prolonged water fluctuation after the Jinghong hydropower dam maintenance since January 2021 (MRC, 2021a) received strong criticism from EoE Study proponents (Eyler et al., 2021; Eyler, 2021a; Price, 2021).

Other reasons why the proponents of the EoE Study present a strong group of narrators lies in open support from environmental activists and other individuals in downstream countries. Since December 2020, the MDM becomes very active in improving its datasets (Basist and Williams, 2021; SC, 2021b) and sharing water-related announcements, including those from the MRC and LMWCIP (LMWCIP, 2020a, 2020b). In practice, it is the civil society in downstream countries that often provide the MDM first-hand information and verify the tangible impacts of natural water flow changes (e.g. MDM-F 2021b, 2021d, MDMT 2021b). While this type of fact-checking has been already institutionalized by the MUP (USE-THA, 2021, EJN 2021), the overdependence on non-water scientists and paying volunteers for "desirable content" raise concerns about the future pathways of the research dialogue. In contrast, since China's government started tackling the ongoing COVID-19 and facilitating the economic recovery of its neighbours through the Lancang-Mekong Cooperation (LMC) (MOFA PRC 2021a, 2021b), the most significant attempt to address the politicization of Chinese mainstream dams have been found in conducting the "Joint Study on the Changing Pattern of Hydrological Conditions in the Lancang-Mekong River Basin and Adaptation Strategies" and advancing the research collaboration with regional partners, particularly with the MRC (SCPRC, 2021; MOFA PRC, 2021b; MRC, 2020c).

Until now, the proponents of the EoE Study often perceive these activities as highly insufficient and too slow considering the vast potential of the LMC (Grünwald, 2020). Nevertheless, sharing the operational hydrological data is still controversial among riparian states (see Matthews and Geheb, 2015; Mirumachi, 2015; Molle et al., 2009). For some, it presents the ideological tool promoting the comprehensive basin development (Backer, 2007; Sneddon and Fox, 2006) and limiting the speculations about the planned water projects (Thu and Wehn, 2016; Cronin and Hamlin, 2010). Others interpret sharing the hydrological data as an essential international right and as a minimum commitment in tackling the political animosities among multi-stakeholders (Hutjens et al. 2016; Gerlak and Schmeier, 2014). Hence, promoting various data exchanges and using remote sensing data for dealing with a lack of information is fully rational and highly beneficial for further transboundary 245 water cooperation. Yet, such a symbolic practice should be also associated with facilitating the accountable research dialogue over these datasets and building the verification mechanisms to distinguish the asymmetrical quality of the research inputs. 


\subsection{Alignment of the Eyes on Earth Study with standard research procedures}

In this section, we have drawn on the contemporary theories of politicization of science (Moges et al., 2021; Atkins, 2019; Thu and Wehn, 2016) and used the adapted Baker's model (Baker, 2016) to examine the alignment of the Eyes on Earth Study with the standard research procedures (see Table 5).

\begin{tabular}{|c|c|c|c|}
\hline Issue & $\mathbf{Y} / \mathbf{N}$ & Results & References \\
\hline Selective reporting & Yes* & $\begin{array}{l}\text { - Using a simple bucket model to determine the alteration of the water flow by Chinese mainstream dams } \\
\text { - Excluding the left-bank tributaries and other environmental cumulative effects from the analysis }{ }^{1} \\
\text { - Limited corrections and no significant changes after controversies over the research conclusions }{ }^{2}\end{array}$ & $\begin{array}{l}\text { Kallio and Fallon, 2020; } \\
\text { MRC, 2020a, 2020b, 2017, 2010; } \\
\text { Eyler et al., 2020a; SC, 2021b }\end{array}$ \\
\hline Pressure to publish & Yes* & $\begin{array}{l}\text { - Funded by the U.S. Department of State through the Lower Mekong Initiative (LMI) } \\
\text { - Necessity to address the occurrence of severe droughts in July } 2019 \text { and estimate the amount of "missing water" } \\
\text { - Within } 3 \text { days, it has been followed by Stimson Center Commentary to raise awareness about the EoE Study }\end{array}$ & $\begin{array}{l}\text { Basist and William,s 2020a, 2020b; } \\
\text { Eyler and Weatherby, 2020; } \\
\text { Basist et al., 2020; } \\
\text { Eyler et al., 2020a }\end{array}$ \\
\hline Quantitative analysis & Yes & $\begin{array}{l}\text { - Using the MRC data and land surface wetness index to monitor the river discharge in the } 28 \text { years } \\
\text { - The changes in the inter-annual natural water flow have been calibrated to Chiang Saen gauge } \\
\text { - Authors plan to observe Sekong, Nam Ou and other river tributaries to monitor the impact of hydropower dam }\end{array}$ & $\begin{array}{l}\text { Basist and Williams, 2021, 2020a } \\
\text { Eyler, 2021b; } \\
\text { Eyler et al., 2020 }\end{array}$ \\
\hline Replicability & Yes & $\begin{array}{l}\text { - Wetness index used at Zambezi and Mekong River and it is } 89 \% \text { accurate to simulate the natural water flow } \\
\text { - Wetness index is expected to be applied on other international rivers with limited access to hydrological data } \\
\text { - More research needs to be done to compare the effectiveness of the wetness index with other hydrological methods }\end{array}$ & $\begin{array}{l}\text { Basist et al., 2020, 2018, 2001; } \\
\text { Eyler et al., 2020a; } \\
\text { Blankespoor et al., } 2018 \\
\end{array}$ \\
\hline Sufficient mentoring & Yes & $\begin{array}{l}\text { - In collaboration with the LMI, United Nations Environmental Program (UNEP), Pact and Stimson Center } \\
\text { - No draft or final review of the EoE Study have been consulted since the MRC provided the datasets } \\
\text { - Uncertain which Chinese multi-stakeholders have been contacted to provide feedback to the EoE Study }\end{array}$ & $\begin{array}{l}\text { Eyler and Weatherby, 2020; } \\
\text { MRC, 2020a; Van, 2020; } \\
\text { Niseyi, 2020; Eyler, 2020; } \\
\text { Eyler et al. 2020a }\end{array}$ \\
\hline Clear methodology & No* & $\begin{array}{l}\text { - Unclear application of the MRC datasets and undefined solutions for removing the biases in datasets } \\
\text { - Unexplained influence of groundwater and accumulated rainfall from previous years } \\
\text { - Plans to co-develop water knowledge and promote citizen science with civil society }\end{array}$ & $\begin{array}{l}\text { EJN, 2021; Eyler et al., 2021, 2020a; } \\
\text { SC, 2021a; } \\
\text { Kallio and Fallon, 2020; } \\
\text { Ketelsen, Sawdon and Räsären, } 2020\end{array}$ \\
\hline Experimental design & Yes & $\begin{array}{l}\text { - Using undertested Special Sensor Microwave Imager/Sounder (SSMI/S) regression model } \\
\text { - Wetness index primarily used for smart agriculture rather than hydrological assessment } \\
\text { - More innovative way to fill the information gaps and highly understandable for civil society }\end{array}$ & $\begin{array}{l}\text { Basist and Williams, 2020a; } \\
\text { Eyler and Weatherby, 2020; } \\
\text { MRC, 2020a }\end{array}$ \\
\hline Transparent datasets & Yes* & $\begin{array}{l}\text { - The visualized data samples are publicly available and reasonably visualized } \\
\text { - The data and methods are operationalized at the MDM Facebook, MDM Twitter and Stimson Center websites } \\
\text { - Majority of the MDM indicators (4/13) do not draw on MRC existing hydrological dataset nor LMWCIP data }\end{array}$ & $\begin{array}{c}\text { SC, 2021b; Basist et al., 2020; } \\
\text { Basist and Williams, 2021; } \\
\text { Eyler et al., 2020a; } \\
\text { MRC, 2020a }\end{array}$ \\
\hline Fraud & No* & $\begin{array}{l}\text { - The interpretation of the EoE Study beyond data was made by Stimson Center, not by EoE Study authors } \\
\text { - No high-quality research study proofing the new evidence has been published in high-impact journals, yet } \\
\text { - Since the EoE Study was reviewed multiple times, it is highly unlikely that the data was anyhow manipulated }\end{array}$ & $\begin{array}{l}\text { CSDS, 2021, 2020a, 2020b; } \\
\text { Ketelsen, Sawdon and Räsären, 2020; } \\
\text { MRC, 2020a; Eyler et al 2021 }\end{array}$ \\
\hline Peer review process & No* & $\begin{array}{l}\text { - No clues indicating that the EoE Study underwent the standard peer-review process } \\
\text { - Highly unlikely that the EoE Study has not been reviewed among its partners } \\
\text { - Since August 2021, the MRC becomes a member of the FLM to advance the collaboration with the MDM }\end{array}$ & $\begin{array}{l}\text { USE-CAM, 2021; } \\
\text { Basist and Williams, 2020a; } \\
\text { MRC, 2021b }\end{array}$ \\
\hline Literature review & Yes* & $\begin{array}{l}\text { - Limited references on the contemporary research studies and using references on outdated research papers } \\
\text { - No references on long-term conclusions from the MRC long-term studies } \\
\text { - No references on existing Chinese research regarding the Lancang-Mekong River water flow }\end{array}$ & $\begin{array}{c}\text { MRC, 2020a; } \\
\text { Kallio and Fallon, 2020; } \\
\text { Ketelsen, Sawdon and Räsären, } 2020\end{array}$ \\
\hline Argumentation & Yes* & $\begin{array}{l}\text { - The EoE Study has been published outside of standard research channels } \\
\text { - Published without subsequent high-quality research studies in indexed research journals } \\
\text { - Arguments have been developed in public media, public-research meetings and other isolated platforms }\end{array}$ & $\begin{array}{l}\text { Grünwald, Feng and Wang, 2021; } \\
\text { Ketelsen, Sawdon and Räsären, 2020; } \\
\text { Van, 2020; Niseyi, 2020; Eyler, 2020 }\end{array}$ \\
\hline
\end{tabular}

*Indicates general inclination rather than a firm conclusion

${ }^{1}$ EoE Study authors rejected the assumption that the water changes can be significantly influenced by tributaries in Myanmar and Laos.

${ }^{2}$ Despite some reflection of the criticism (Basist and Williams, 2021; Basist and Williams, 2020b), the EoE Study conclusions remain unchanged.

${ }^{2}$ EoE Study authors have closely collaborated with the Stimson Center despite they have not been mentioned in the final version of the manuscript.

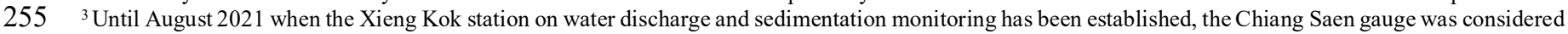
one of the northmost hydrometeorological stations within the Mekong Basin.

${ }^{4}$ No evidence and any electronic correspondence has been found to verify the author's effort to consult the research results with Chinese stakeholders.

${ }^{5}$ Until now, there is no evidence that EoE Study authors invited Chinese researchers to research dialogue over the EoE Study.

Table 5. Research assessment of the politicization of the Eyes on Earth Study

260 Our data show that the EoE Study has been published outside of the standard research channels and has not been followed up by any associated research article published in high-impact factor journals that will appropriately develop the research findings. Also, despite the EoE Study findings have been operationalized in the MDM (Basist et al., 2020; Eyler et al., 2020a) and widely discussed at various public-research platforms (EJN, 2021; Keshap, 2021; SC, 2021a, 2020; Basist et al., 2020; Eyler et al., 2020b), the contemporary Chinese research studies on the Lancang-Mekong River (e.g. Hou et al., 2021; Li et al., 2021; 265 Tian et al., 2020; Sun et al., 2019; Lu et al., 2018) remain marginalized. Regarding the technical design of the EoE Study, 
authors have chosen the wetness index over other remote sensing methods (e.g. Standardized Precipitation Evapotranspiration Index, Standardized Precipitation Index) that may be more suitable for monitoring the complex hydrological changes in international rivers (Basist et al., 2018; Blankespoor et al., 2018; Basist et al., 2001) without further explanation. Other technical issues include the lack of hydrological assessment of upstream (e.g. Manzhang, Manan, Liusha and Nanban Rivers) and downstream tributaries (e.g. Ruak/Nam Mae Sai River, Nam Yawng River or Nam Ou Rivers), number of references on outdated research studies and insufficient review of the MRC long-term observations on the environmental cumulative impact on the natural water flow (see Grünwald, Feng and Wang, 2021; Zhang et al., 2020; Kallio and Fallon, 2020; MRC, 2020a, 2020b, 2017, 2010).

Finally, by exploring the form of argumentation, the main discussion over the EoE Study findings have occurred in "isolated research platforms" without China's involvement (e.g. CSDS, 2021; SC, 2021a; EWC, 2021; FCCT, 2020) and have been developed in the public (e.g. Van, 2020; Niseyi, 2020; Eyler, 2020; Eyler et al., 2020b) and official media (e.g. Stilwell, 2020a, PRC-EUS, 2020; PRC-ECA, 2020) with a limited reflection of the contemporary research commentaries (MRC, 2020a, Ketelsen, Sawdon and Räsären, 2020; Kallio and Fallon, 2020; CSDS, 2020a, 2020b). However, since the EoE Study received a very shallow and indirect official response from downstream governments (Grünwald, Feng and Wang, 2021; SC, 2020a;

280 MDM-T, 2020), it seems there is less political confidence over the EoE Study conclusions that the mainstream media illustrate. Also, since none of the riparian researchers has been officially involved in the MDM advisory board (Basist et al., 2020), the MDM remains an exclusive research platform fully depending on the US water knowledge. Last but not least issue present the decentralization of the research process. So far, the main input for the MDM announcement was derived from foreigners living in downstream countries (e.g. MDM-F, 2021d) and occasionally from the environmental NGOs concerning the local water issues (e.g. MDM-F, 2020b). Unlike the successful citizen science initiatives such as Thai Baan research (e.g. Heis and Vaddhanaphuti, 2020; Kircherr, 2019), such research decentralization seems more focused on providing audio-visual materials for US-funded journalists (USE-THA, 2021; EJN, 2021) rather than systematic hydrological monitoring and incentives for further collaboration with the regional water institutions in downstream countries.

\subsection{Eyes on Earth Study implications on accountable research dialogue}

290 To better illustrate the positive and negative implications of the politicization of the EoE Study, we created the list of ongoing discourses practices associated with the MDM operationalizing the EoE Study findings (Table 6) and added a detailed chronology of 239 events visualizing the multifarious feedback on the EoE Study and MDM in the context of transboundary water governance (see Table S1). While the majority of events present intergovernmental meetings, official press conferences and other relevant events advancing the water cooperation, we also include other activities advancing the joint research 295 dialogue in the Lancang-Mekong River. In addition, we also studied various notifications from the MDM websites and tracked a plethora of public-research activities of the EoE Study/MDM leading authors to better understand the current development pathways in the Lancang-Mekong research dialogue. 


\begin{tabular}{|c|c|c|}
\hline & Limiting research dialogue & Facilitating research dialogue \\
\hline \multicolumn{3}{|l|}{ I. Scientific role } \\
\hline Interpretation & $\begin{array}{l}\text { - Simplification of the cumulative environmental impacts } \\
\text { - Use of the non-scientific jargon to attract more media attention } \\
\text { - Speculate about water fluctuations without robust evidence } \\
\text { - Mainly focus on Chinese mainstream dams ( } 70-90 \% \text { of MDM content) }\end{array}$ & $\begin{array}{l}\text { - Adapting content to non-scientists to overcome the knowledge gap } \\
\text { - Raising public awareness about environmental issues } \\
\text { - Frequent notifications and announcements on the MDM websites } \\
\text { - Put more pressure on investigating tributary dams in the } 3 \mathrm{~S} \text { Basin }\end{array}$ \\
\hline Authority & $\begin{array}{l}\text { - MDM authors fully control the content of the MDM database } \\
\text { - Knowledge is co-produced by US agencies and non-state actors } \\
\text { - MDM does not acknowledge existing MRC/Chinese research studies } \\
\text { - MUP overlaps with the MRC and LMWCIP agenda (no mandate) }\end{array}$ & $\begin{array}{l}\text { - MDM encourages journalists to use MDM and write their stories } \\
\text { - MDM serves as a basis for promoting public-research dialogue } \\
\text { - MDM models deal with a lack of operational hydrological data } \\
\text { - MUP accelerates the water cooperation with foreign donors }\end{array}$ \\
\hline Research environment & $\begin{array}{l}\text { - Methodological and other technical shortcomings of the wetness index } \\
\text { - Biases in the EoE Study and MDM datasets } \\
\text { - MDM develops arguments outside of the traditional research channels } \\
\text { - MDM conclusions do not align with standard research procedures }\end{array}$ & $\begin{array}{l}\text { - Providing detailed methodology on the Stimson Center websites } \\
\text { - Interactive, user-friendly, publicly accessible and free database } \\
\text { - MDM includes feedback from water practitioners and local people } \\
\text { - MDM conclusions build upon the long-term mainstream dam concerns }\end{array}$ \\
\hline \multicolumn{3}{|l|}{ II. Performance } \\
\hline Scientific style & $\begin{array}{l}\text { - MDM rarely responds to critique from international researchers } \\
\text { - MDM occasionally use non-scientific jargon and biased rhetoric } \\
\text { - MDM exercises over-confidence over its research conclusions }{ }^{1} \\
\text { - MUP legitimize the accuracy of datasets by non-water experts }\end{array}$ & $\begin{array}{l}\text { - MDM shares citizen-science activities and other MDM achievements } \\
\text { - MDM updates on Stimson Center are timely and reasonably notified } \\
\text { - MDM collects more information before outlining feasible solutions } \\
\text { - MUP actively interacts with the MRC and other foreign donors }\end{array}$ \\
\hline Dynamics & $\begin{array}{l}\text { - MDM received shallow and indirect support from downstream governments } \\
\text { - MDM models use stereotypes to support their conclusions }{ }^{2} \\
\text { - MDM shares datasets without achieving research consensus } \\
\text { - MDM authors speeding up research through non-traditional platforms }\end{array}$ & $\begin{array}{l}\text { - MDM facilitates unofficial policy-research dialogue with policy-makers } \\
\text { - MDM mobilized US assets existing and resources to multiply the benefits } \\
\text { - MDM maps are accurate enough to track sudden water changes } \\
\text { - MDM enlarges the target audience outside of the Lancang-Mekong Basin }\end{array}$ \\
\hline Dialogue & $\begin{array}{l}\text { - Predominant politicization of Chinese dams and other actions } \\
\text { - MUP agenda does not consider further collaboration with China } \\
\text { - No consultation over the MDM conclusions before posting on social media } \\
\text { - No consideration of the positive effects of dams on the water flow } \\
\end{array}$ & $\begin{array}{l}\text { - Putting more pressure on strengthening water cooperation with China } \\
\text { - MUP contests China's role in complex basin development } \\
\text { - Encourages LMWCIP to re-consider communication and notification mode } \\
\text { - MUP motivates civil society to engage in transboundary water governance }\end{array}$ \\
\hline \multicolumn{3}{|l|}{ III. Identification } \\
\hline Determination & $\begin{array}{l}\text { - Lack of transparent hydrological data about upstream water operations } \\
\text { - Marginalization of the non-mainstream dam cumulative effects }{ }^{3} \\
\text { - Research uncertainties and conflict of interests } \\
\text { - Interpretation of the hydrological findings beyond data }\end{array}$ & $\begin{array}{l}\text { - Improve transparency of hydrological data through remote sensing } \\
\text { - Explore the water peaking caused by the hydropower dam operations } \\
\text { - Advance collaboration with regional partners, particularly with the MRC } \\
\text { - Re-considering transboundary water management practices } \\
\end{array}$ \\
\hline Facilitators & $\begin{array}{l}\text { - Communication shortcomings of the LMWCIP } \\
\text { - Insufficient networking with Chinese multi-stakeholders } \\
\text { - Data inconsistencies between MDM, MRC and LMWCIP } \\
\text { - Rise of anti-scientific movements disturbing the plurality of viewpoints } \\
\end{array}$ & $\begin{array}{l}\text { - MDM provides additional information to existing mechanisms } \\
\text { - Improving the wetness index to provide higher accuracy predictions } \\
\text { - Closer collaboration with regional partners, particularly the MRC } \\
\text { - Co-produce and develop indigenous water practices and local knowledge } \\
\end{array}$ \\
\hline Identities & $\begin{array}{l}\text { - MUP tends to enforce normative standards by "blame game" scheme }{ }^{5} \\
\text { - MDM narrows the plurality of views on cumulative environmental impacts } \\
\text { - Further water cooperation is pushed by MUP than Mekong governments } \\
\text { - Marginalize joint responsibility for transboundary water management }\end{array}$ & $\begin{array}{l}\text { - MUP as the "moderator with muscles" to ensure stricter water regime } \\
\text { - MDM as a tool to overcome existing information gaps in water science } \\
\text { - Continue in the US legacy in Southeast Asia (draw on the MRC and LMI) } \\
\text { - Unite downstream countries to set hydrological monitoring as a top priority }\end{array}$ \\
\hline \multicolumn{3}{|l|}{ IV. Perception } \\
\hline Outcomes & $\begin{array}{l}\text { - Mismatched the EoE Study and Stimson Center commentary } \\
\text { - Caused distrust towards new research studies correcting the MDM conclusions } \\
\text { - Transferred resentment from dam operators to Mekong governments } \\
\text { - MDM overshadowed the MRC and LMWCIP hydrological monitoring }\end{array}$ & $\begin{array}{l}\text { - Motivated China to set more ambitious goals in water cooperation } \\
\text { - Provided hope for increasing sustainability of the Lancang-Mekong River } \\
\text { - Showed the empathy of the international community with current water issues } \\
\text { - Encouraged MRC and LMWCIP to innovate their current agenda }\end{array}$ \\
\hline Processes & $\begin{array}{l}\text { - MDM authors more stepped in geopolitical debates than feasible solutions }{ }^{10} \\
\text { - No high-quality research article follows up since the establishment of the MDM } \\
\text { - Ostracization of the scientists sharing different views on the MDM } \\
\text { - Dependence on western and other foreign experts over the water situation }\end{array}$ & $\begin{array}{l}\text { - Exposed the need for the reliable fact-checking mechanisms } \\
\text { - Re-emphasized the problem of different quality of hydrological studies } \\
\text { - Highlighted the problem of interpretation of water science by non-scientists } \\
\text { - Showed the lack of understanding of the pace of accountable research work }\end{array}$ \\
\hline
\end{tabular}

300 Williams, 2021) and the MDM scientists willingness to deal with biases in datasets (SC, 2021a) may indicate the positive change in the research mindset. ${ }^{2}$ For example, not every dry season are droughts, not every average dry event is extreme, calculating the wetness index without addressing different soil retention capacities, using "cloud-piercing" satellites tracking the basin water levels without considering the different density of forested areas, etc.

${ }^{3}$ For example, unaddressed impact of sand-mining, modernization of agriculture practices, water conservation, irrigation and other water-related projects.

${ }^{4}$ The Eyes on Earth is widely considered as an independent NGO regardless of its connections to the US government funding (LMI 2019a, 2019b).

$305{ }^{5}$ Since December 2020, the MDM has predominantly focused on China's biggest dams (notably Nuozhadu, Xiaowan and Huandeng) and several controversial dams in Sekong-Srepok-Sesan Basin (particularly Lower Sesan II, Xayaburi, Xepian-Xenamnoy and Yali Falls). However, the impact of upstream tributary water projects in the Golden Triangle (Myanmar, Thailand, Laos) and Lower-Lancang River (China) remains unanswered.

${ }^{6}$ The US government was a historical patron of the basin development since 1953 not only to promote peace among Southeast Asian nations but also to ensure its influence in Thailand military outputs and deter the spread of communism during the Cold War in Southeast Asia (Glassman, 2003).

$310{ }^{7}$ Since most of the MDM calls for better transparency of the operational hydrological data have been related to the Chinese and Laotian mainstream dams, more information gaps about other ongoing downstream hydropower dams need to be addressed (Zhong et al 2016, Mirumachi 2015).

${ }^{8}$ Most of the references mismatch the EoE Study for the Stimson Center commentary which already develops the EoE Study conclusions (see Table S1).

${ }^{9}$ While most of the pressure to change the water utilization practices is paid to the Lancang-Mekong policy-makers, the dam operators, sub-contractors, financial institutions and other assistant companies backing these projects remain widely overlooked.

$315{ }^{10}$ Apart from MDM water science activities, some of the MDM authors are very active in outlining Lancang-Mekong multi-stakeholders ulterior motives, identifying contemporary political-security threats in Southeast Asia and speculating about the political-ecological implications of dams both individually (e.g. Eyler et al 2021, Eyler et al 2020b, Eyler 2020) or on behalf of the MDM (e.g. MDM-T 2021b, 2020, MDM-F 2020).

Table 6. Summary discourse practices exercised by the Mekong Dam Monitor and Mekong-U.S. Partnership 
Contradictory to existing knowledge, the strengthening of the hydrological data sharing via the LMWCIP and MDM has not been initiated by the politicization of the EoE Study but by China's willingness to advance existing water cooperation with Mekong countries since December 2019 (MOFA PRC, 2020; MRC, 2019a). A similar trend can be also found in terms of the opponents of the EoE Study where critics consider the USA-China geopolitical rivalry and close connection of the Eyes on Earth on US governmental funds as the main trigger for the politicization of science (Grünwald, Feng and Wang, 2021). By investigating the discourse practices limiting and facilitating the research dialogue, we noticed several trends.

Firstly, the Stimson Center's commentary (Eyler and Weatherby, 2020) is more often quoted than the original EoE Study (Basist and Williams, 2020a). Unlike the EoE Study concerning "compounding the alternation of natural river flow" by five Chinese dams built since 2017 (Basist and Williams, 2020a: 18) and stressing that "more research will be required to better understand [the' unnatural flows" (Basist and Williams, 2020a: 17), the Stimson Center's Commentary present the EoE Study findings as a proof "beyond reproach" (Eyler and Weatherby, 2020). This form of justification of research findings combined with using the non-scientific jargon and accusations based on rumours then contributed stronger prejudice against Chinese activities and acceptance of the EoE Study findings in US official discourse without further research consideration (Grünwald, Feng, Wang, 2021: 12, 7).

Secondly, water science along with other scientific fields experience severe crisis (Pardini et al., 2021; Sarewitz, 2015). Partially because of the systemic failures, human errors and other unintentional consequences during the research observation (de Zwart, 2015). But most importantly, there is a lack of trust in the standard research procedures where anyone can stir up doubts about the long-term findings without producing higher scientific inputs. While such behaviour is usually expected from the non-scientific community whose knowledge gap and expectations about the pace of the research process are far beyond the expectations (Pielke, 2004), using the numerous "research shortcuts" by scientists (i.e. publishing the research without peer-review and through non-scientific channels) to speed up the standard research procedures and justify contradictory solutions for facilitating the research dialogue (i.e. calling for better communication with Chinese stakeholders without incorporating this goal into the MDM agenda) slowly becomes a "new normal" of politicization of water science.

Thirdly, there is an issue of better transparency of the hydrological data from upstream countries and preventing data biases (Price, 2021; CNMC, 2021; MRC, 2021a, 2020c). To date, there are 68 hydrological stations within the basin (MRC, 2021a, 2021c, 2021d). The most important information about upstream operations come from Jinghong and Manan hydrometeorological monitoring station in the Lower Lancang River and Xieng Kok, the northernmost station between Laos and Myanmar. Although the MDM authors showed a strong willingness to incorporate non-Chinese reservoirs such as Nam Ou, Nam Khan and Sekong rivers to test their models (Eyler, 2021b; Eyler et al., 2020), the persisting biases in the MDM datasets (MDM-F, 2021c; Eyler et al., 2021) and MRC concerns over the misinterpretation of the EoE Study conclusions (MRC, 2020a) continue to co-develop multiple speculations. A similar problem can be also found in terms of the LMWCIP where data inconsistencies over the water discharge need to be significantly improved (LMWCIP, 2021b; MRC, 2021a, 2021d, 2021e). 
Fourthly, there is an issue of water fluctuation and timely notification of any abnormal water changes. While both proponents and opponents are seeking better accuracy of the hydrological data models, the low flow itself is not a problem. The actual problem lies in unacknowledged temporal water fluctuations of Chinese mainstream dams (MRC, 2021b, 2019b, 2019c) and fragmentation of the accountable research dialogue (Grünwald, 2021; CSDS, 2021, 2020a, 2020b, 2020c). Such a trait can be specially identified in terms of scheduled upstream water operations (LMWCIP 2021a; LMWCIP 2021c; MRC 2021a, 2021d) and sudden water fluctuations caused by hydro-meteorological changes (MRC 2021f, 2021g, MDM-T 2020c). In the past, some MDM observers considered water fluctuation as unprecedented proof of "manipulating the water flow" and as a failure of the LMWCIP to timely notify the downstream countries (Eyler, 2021a). Soon after, it turned out that the Jinghong dam maintenance was scheduled a year earlier (LMWCIP, 2019). Nevertheless, there is always space for an improvement, particularly in terms of when China's Ministry of Water resources should send the notification to downstream governments in advance and how much water should be restored after any temporal water fluctuation caused by the upstream operations (MRC, 2021f, 2021g).

\section{Discussion and conclusions}

\subsection{Socio-hydrological framework}

365 The presented framework has been designed to visualize the socio-hydrological pathways and factors affecting the dynamics of the accountable research dialogue in the Lancang-Mekong Basin. As shown in Figure 2, the framework is built upon the socio-hydrological works conceptualizing the human-water interaction (Madani and Shafiee-Jood, 2020; Evers et al. 2017; Lane, 2014). By considering the contemporary conflict of ideas over the EoE Study conclusions, we studied the correlation patterns between (a) discourse practices, (b) water narratives and (c) multi-stakeholders inputs in the last 18 months (April 2020-September 2021). To outline the causal relations in the accountable research dialogue (d), we analysed the contrast between the standard and alternative research procedures (e, f), and considered various external factors (i) demonstrating the nuances in the actual human water interaction. Contradictory to popular narratives illustrating any water dispute as an obstacle in transboundary water management (e.g. driven by growing water consumption, ineffective water practices, insufficient legal system) and transboundary water governance (e.g. driven by lack of multi-level coordination, incoherent research communication), we believe that any progress requires a certain time to adapt a new way of thinking in practice. Therefore, whenever multi-stakeholders agree or disagree on specific water issues, multi-stakeholders code of conduct, values, mandate, mindset, motives, access to research dialogue, research integrity, identity, capacity, power status and experience along with other factors should be put in further consideration. 


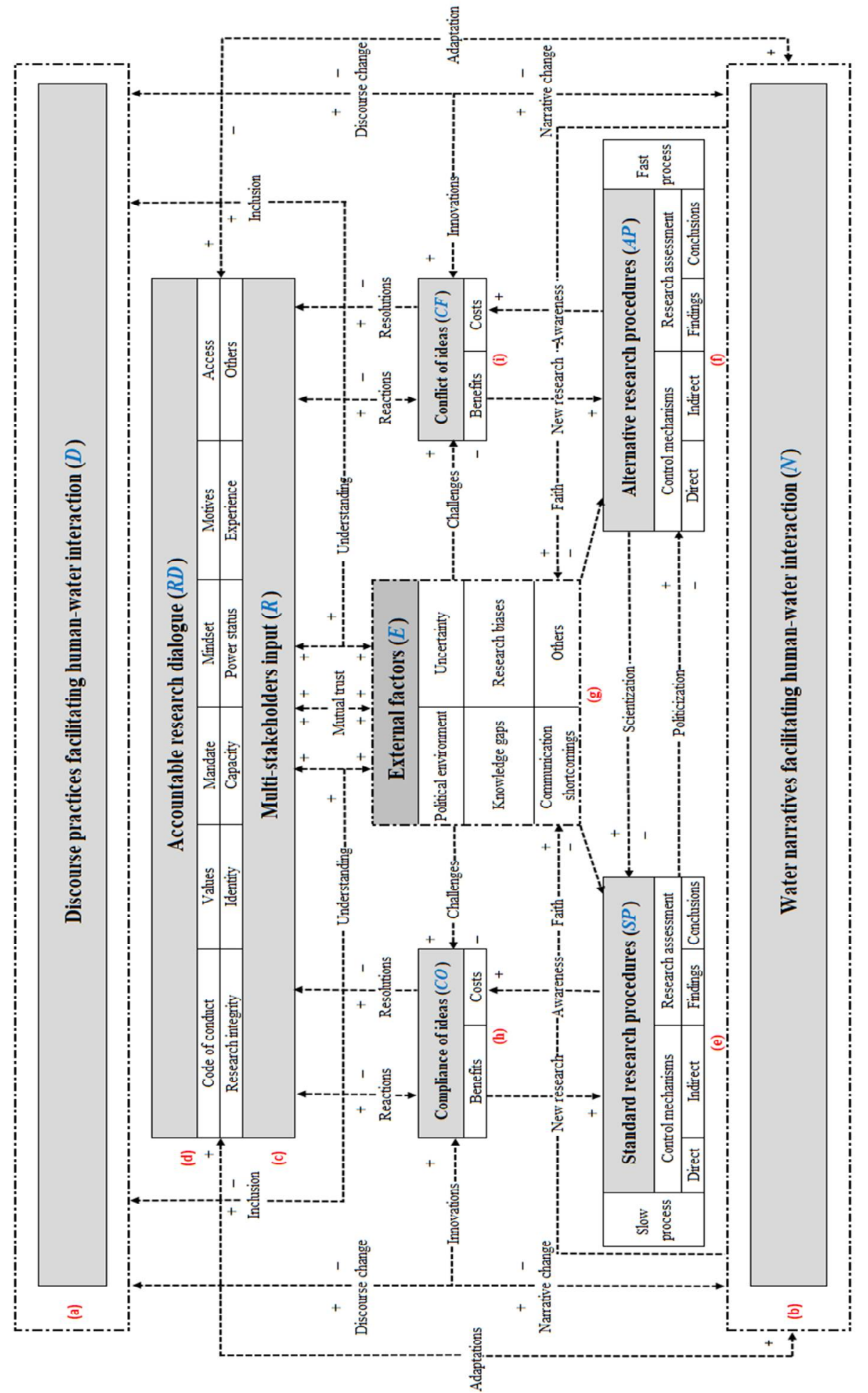

Figure 2. Accountable research dialogue diagram showing the complexity and interlinkages in human-water interaction 


\subsubsection{Socio-hydrological mechanism}

The presented equation describes the mechanism facilitating the accountable research dialogue during the politicization of water science. Unlike the equations considering the entanglement of different sectors (Di Baldassarre et al., 2013a) or system components in cooperation and conflict (Wei et al., 2021), we consider the accountable research dialogue as an interchanging competitive process in which multi-stakeholders constructively propose the feasible solutions, build mutual trust and jointly fill the information gaps in an appropriate manner. The dashed arrows indicate the actual changes and evolution of the accountable research dialogue in time and space. The plus $(+)$ and minus $(-)$ symbols represent the expected outcomes and causal relations between variables. For simplification, we outlined the binary choices from these coupled processes and showed the theoretical inclination of several variables affecting the human-water interaction. Thus, the formula clarifying the pathways for establishing the accountable research dialogue is set as follows:

$R D_{x y}=\frac{\frac{R_{x}(C O-C F)}{\mathrm{D}+\mathrm{N}}+\frac{R_{y}(S P-A P)}{\mathrm{D}+\mathrm{N}}}{E}$

where,

$\mathrm{RD}_{\mathrm{xy}}=$ Accountable research dialogue among multi-stakeholders

$\mathrm{R}_{\mathrm{x}}=$ Multi-stakeholder interaction (Policy-makers)

$395 \mathrm{R}_{\mathrm{y}}=$ Multi-stakeholders interaction (Researchers)

$\mathrm{CO}=$ Compliance of ideas

$\mathrm{CF}=$ Conflict of ideas

$\mathrm{D}=$ Discourse practices

$\mathrm{N}=$ Water narratives

$\mathrm{E}=$ External factors

As shown in Table 7, there can be identified dozens of inputs produced by multi-stakeholders. By dividing these inputs into three groups (standard, alternative and other), we noticed a significant disproportion between research and policy responses. While the $R D$ was mainly dominated by $R_{x 1-3}$ organizing multifarious meetings with downstream officials and by $R_{y 4-5}$ initiating the public-science encounters about the $D$, the $C O$ seems to be highly affected by the $E$ and existing shortcomings in the $A P$.

405 So far, most of the written research responses towards the EoE Study and MDM were published in $A P$ whereas only very few inputs underwent the SP (e.g. Keovilignavong, Nguyen and Hirsch, 2021; Grünwald, Feng and Wang, 2021). Another interesting trend can be found in terms of timing and feedback to the multi-stakeholders inputs. While most of the references on the EoE Study from the $R_{x 1-3}$ oscillated in April 2020 (i.e. publishment of the EoE Study), September-November 2020 (i.e. launching the MUP, LMWCIP, MDM) and February-March 2021 (i.e. water flow changes and communication shortcomings

410 from the LMWCIP), the responses from the $R_{y 1-5}$ were more systemic and complex. However, the number of the standard scientific responses to the EoE Study (i.e. respond papers, research articles, reports) is significantly lower than the total number of the alternative research inputs (e.g. public-science meetings, interviews and other conferences). 


\begin{tabular}{|c|c|c|c|}
\hline \multirow{2}{*}{ Stakeholders } & \multicolumn{3}{|c|}{ Responses } \\
\hline & Standard & $\begin{array}{r}\text { Alternative } \\
\end{array}$ & Other \\
\hline $\begin{array}{c}\text { EoE Study } \\
\text { authors }\left(R_{y 1}\right)\end{array}$ & - N/A & $\begin{array}{l}\text { - EoE Study (April 2020) } \\
\text { - EoE Study researcher's commentary (April 2020) } \\
\text { - EoE Improvement report (June 2021) } \\
\end{array}$ & - SC-EoE Study researcher commentary (July 2020) \\
\hline $\begin{array}{l}\text { US researchers } \\
\qquad\left(R_{y 2}\right)\end{array}$ & $\begin{array}{l}\text { - } \text { MDM has been launched (December 2020) } \\
\text { - } 1^{\text {st }} \text { and } 2^{\text {nd }} \text { MDM alert (January 2021) } \\
\text { - } 3^{\text {td }} \text { MDM alert (February 2021) } \\
\text { - } 4^{\text {th }}-6^{\text {th }} \text { MDM alert (March 2021) } \\
\text { - } 7^{\text {th }}-9^{\text {th }} \text { MDM alert (April 2021) } \\
\text { - } 10^{\text {th }}-16^{\text {th }} \text { MDM alert (May 2021) } \\
\text { - } \text { MDM launched a major update (June 2021) } \\
\text { - } 17^{\text {th }}-19^{\text {th }} \text { MDM alert (July 2021) } \\
\text { - } 20^{\text {th }} \text { MDM alert (September 2021) } \\
\end{array}$ & $\begin{array}{l}\text { - Stimson Center commentary (April 2020) } \\
\text { - Indo-Pacific Conference (October 2020) } \\
\text { - MDM announced biases in datasets (April 2021) } \\
\text { - MDM informal online meeting (April 2021) } \\
\text { - MDM informal online meeting (May 2021) } \\
\text { - MDM informal online meeting (June 2021) } \\
\text { - MDM virtual workshop (August 2021) }\end{array}$ & $\begin{array}{l}\text { - SC researcher commentary (April 2020) } \\
\text { - SC researcher commentary (May 2020) } \\
\text { - SC and EoE Study authors commentary (May 2020) } \\
\text { - SC researcher commentary (June 2020) } \\
\text { - SC-EoE Study authors commentary (July 2020) } \\
\text { - SC researcher commentary (January 2021) } \\
\text { - SC researcher commentary (January 2021) } \\
\text { - SC and Can Tho University commentary (May 2021) } \\
\text { - SC researcher webinar (June 2021) } \\
\end{array}$ \\
\hline $\begin{array}{l}\text { Chinese } \\
\text { researchers } \\
\left(R_{y 3}\right)\end{array}$ & $\begin{array}{l}\text { - } 3^{\text {rd }} \text { International Water Security Forum (April } \\
2021 \text { ) }\end{array}$ & $\begin{array}{l}\text { - Tsinghua University Study (July 2020) } \\
\text { - Lu Xing commentary (July 2020) } \\
\text { - Zhong Yong commentary (October 2020) } \\
\text { - Xingjun Yu commentary (December 2020) }\end{array}$ & - Tsinghua University commentary (August 2020) \\
\hline $\begin{array}{l}\text { Interdisciplinary } \\
\text { researchers } \\
\left(\boldsymbol{R}_{\boldsymbol{y} 4}\right)\end{array}$ & $\begin{array}{l}\text { - CSDS Dialogue Forum } 4 \text { Mekong (July 2020) } \\
\text { - CSDS-CDRI report (August 2021) }\end{array}$ & $\begin{array}{l}\text { - } \text { AMPERES commentary (April 2020) } \\
\text { - Aalto university commentary (April 2020) } \\
\text { - CSDS seminar on the EoE Study (August 2020) } \\
\text { - CICP Conference on Sustainable Mekong } \\
\text { (October 2020) } \\
\text { - CICP webinar on US-China (March 2021) } \\
\text { - EWC Dialogue (April 2021) } \\
\text { - Chulalongkorn University and SEVANA } \\
\text { researcher commentary (May 2021) }\end{array}$ & $\begin{array}{l}\text { - FCCT public discussion on EoE Study (April 2020) } \\
\text { - Webinar on China-Southeast Asia (September 2020) } \\
\text { - Webinar on Damming the Mekong (September 2020) } \\
\text { - Webinar on China-India Politics (November 2020) } \\
\text { - Webinar on Chinese projects (November 2020) } \\
\text { - CICP webinar on ASEAN (January 2021) } \\
\text { - CICP webinar on US-China (May 2021) } \\
\text { - CSIS webinar on US-Laos Partnership (September } \\
\text { 2021) }\end{array}$ \\
\hline $\begin{array}{c}\text { Intergovernmental } \\
\text { institutions and } \\
\text { foreign donors } \\
\left(R_{y 5}\right) \\
\end{array}$ & $\begin{array}{l}\text { - } \text { MRC report on EoE Study (April 2020) } \\
\text { - } \text { MRC report on Chinese dams (August 2020) } \\
\text { - } 1^{\text {st }} \text { ASEAN-MRC Water Security Dialogue } \\
\text { (August 2021) }\end{array}$ & $\begin{array}{l}\text { - UNECE webinar on Data sharing (February 2021) } \\
\text { - Mekong Delta conference (March 2021) }\end{array}$ & $\begin{array}{l}\text { - MRC unofficial commentary (April 2020) } \\
\text { - SUMERNET grant for Mekong journalist (April } \\
\text { 2020) }\end{array}$ \\
\hline $\begin{array}{l}\text { US officials } \\
\quad\left(R_{x I}\right)\end{array}$ & $\begin{array}{l}\text { - Indo-Pacific Conference (October 2020) } \\
\text { - EWC-MUP conference report (February 2021) } \\
\text { - MUP Track 1.5. Policy Dialogue (March 2021) } \\
\text { - } 1^{\text {st }} \text { MUP Track 1.5. Policy Dialogue } \\
\text { (September 2021) }\end{array}$ & $\begin{array}{l}\text { - Michael Pompeo commentary (April 2020) } \\
\text { - Michael DeSombre commentary (April 2020) } \\
\text { - David R. Stilwell commentary (July 2020) } \\
\text { - Michael Pompeo commentary (September 2020) } \\
\text { - David R. Stilwell commentary (October 2020) } \\
\text { - Ned Price commentary (February 2021) } \\
\text { - W. Patrick Murphy commentary (February 2021) } \\
\text { - Atul Keshap commentary (March 2021) } \\
\text { - W. Patrick Murphy commentary (June 2021) } \\
\text { - W. Patrick Murphy commentary (August 2021) } \\
\end{array}$ & $\begin{array}{l}\text { - David R. Stilwell commentary (September 2020) } \\
\text { - David R. Stilwell commentary (December 2020) } \\
\text { - David R. Stilwell commentary (December 2020) } \\
\text { - Mekong People's Council Forum (December 2020) } \\
\text { - EJN-EWC-SC grant for Mekong journalist (February } \\
\text { 2021) } \\
\text { - Kamala Harris commentary (April 2021) }\end{array}$ \\
\hline $\begin{array}{c}\text { Chinese officials } \\
\qquad\left(R_{x 2}\right)\end{array}$ & $\begin{array}{l}\text { - LMWCIP has been launched (November 2020) } \\
\text { - LMWCIP announced the maintenance } \\
\text { (January 2021) } \\
\text { - LMWCIP-MRC water data meeting (March } \\
\text { 2021) } \\
\text { - LMWCIP announced the maintenance (July } \\
\text { 2021) } \\
\text { - LMWCIP postponed the maintenance (July } \\
\text { 2021) }\end{array}$ & $\begin{array}{l}\text { - Shuang Geng commentary (April 2020) } \\
\text { - Keqiang Li commentary (August 2020) } \\
\text { - Lijian Zhao commentary (September 2020) } \\
\text { - Zhaohui Luo commentary (November 2020) } \\
\text { - Zhaohui Luo commentary (November 2020) } \\
\text { - Chunying Hua commentary (December 2020) } \\
\text { - Wenbing Wang commentary (December 2020) } \\
\text { - Chungying Hua commentary (March 2021) } \\
\text { - Wang Yi commentary (June 2021) } \\
\text { - Wenbin Wang commentary (June 2021) } \\
\text { - Keqiang Li commentary (September 2021) }\end{array}$ & - N/A \\
\hline $\begin{array}{l}\text { Downstream } \\
\text { officials and } \\
\text { relevant donors } \\
\quad\left(R_{x 3}\right)\end{array}$ & 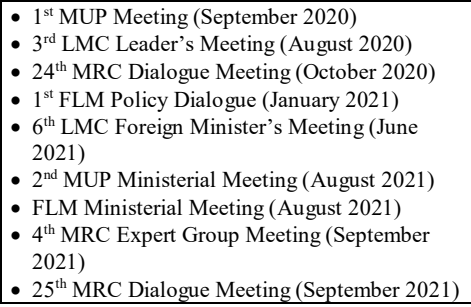 & $\begin{array}{l}\text { - LMC JWG meeting on LMWCIP (May 2020) } \\
\text { - LMC Water Symposium (September 2020) } \\
\text { - } 2^{\text {nd }} \text { LMC JWG meeting on water (September 2020) } \\
\text { - } \text { LMC water resources meeting (October 2020) } \\
\text { - LMC Workshop on Hydropower (October 2020) } \\
\text { - Prak Sokhonn commentary (March 2021) } \\
\text { - LMC delegates commentary (April 2021) } \\
\text { - Sreng Sataro commentary (May 2021) } \\
\text { - } 1^{\text {st }} \text { MUP Senior Official Meeting (June 2021) } \\
\text { - } \text { MUP-SIP training (July 2021) }\end{array}$ & $\begin{array}{l}\text { - Thailand unofficial commentary (April 2020) } \\
\text { - Vietnam unofficial commentary (December 2020) }\end{array}$ \\
\hline
\end{tabular}

Note: Australia-Mekong Partnership for Environmental Resources \& Energy (AMPERES), Cambodian Institute for Cooperation and Peace (CICP), Cambodia Development Resources Institute (CDRI), Center for Social and Development Studies at Chulalongkorn University (CSDS), Environmental Journalist 415 Network (EJN), Eyes on Earth Study (EoE Study), East-West Center (EWC), Friends of the Lower Mekong (FLM), Foreign Correspondents' Club of Thailand (FCCT), Joint Working Group (JWG), Lancang-Mekong Cooperation (LMC), Lancang-Mekong Water Cooperation Information Platform (LMWCIP), Mekong Dam Monitor (MDM), Mekong River Commission (MRC), Mekong-U.S. Partnership (MUP), Sustainable Infrastructure Partnership (SIP), Stimson Center (SC) and United Nations Economic Commission for Europe (UNECE). For more detailed information about the events, please see the Table S1.

Table 7. List of research and policy inputs from multi-stakeholders intended for facilitating the research dialogue 
420 By comparing the normative form of the $R D$ illustrated in Figure 2 with the list of existing research and policy inputs from stakeholders in Table 7, we identified the following correlations:

(1) Multi-level collaboration among $R_{y 4-5}$ positively facilitates the $R D$ and effectively helps with the structural depoliticization of the water science in the $A D$, particularly by the anti-scientific movements;

(2) Increasing data transparency and supporting the $A D$ activities by $R_{y 1-2}$ did not motivate the $R_{x 3}$ and $R_{y 3-5}$ to advance the

water cooperation. The exception presents the establishment of the LMWCIP (November 2020) and MDM (December 2020).

(3) Growing communication access restrictions and marginalization of the $R_{y 3-5}$ research viewpoints contribute to the $C F$ among $R_{x y}$ and expand the scope of the $E$;

(4) Despite the $C O$ among the proponents of the EoE Study, legitimizing the interpretation of the water science beyond data and growing use of the anti-scientific tools in that $A D$ continuously decreasing the quality of the research inputs in the $R D$;

430 (5) The $C F$ over the EoE Study conclusions was primarily driven by $R_{x l-2}$ whose capacity, power status and other motives negatively influence the $R_{x 3}$ bargaining position and finding feasible solutions reflecting their values and national interests; However, by studying the current discourse practices over the EoE Study and MDM, we found several issues which will require further investigations to provide robust evidence. Firstly, $S P$ seems very unattractive for the $R_{x l-3}$ due to the high research costs, immense time requirements and uncertainty with the research conclusions that may not align with their prior beliefs and not provide a plausible explanation of the complex socio-hydrological phenomena (Jasanoff, 1987). Also, by calling the $R_{y 1-5}$ for raising the awareness and conceiving new research regardless of their lack of mandate (i.e. MDM) and research integrity (i.e. overreliance on the $A D$ ), the expected $R D$ changes and all ongoing research on depoliticizing the water science remain unknown.

Secondly, numerous research fallacies and other argumentation techniques are distorting both the $R D$ and $A D$ research communication which was not extensively analysed. While putting the EoE Study conclusions in the non-water and non-basin context along with other speculations may be considered harmless, such water narratives (i.e. comparison of the LancangMekong water disputes with Himalayan and South China Sea disputes) may negatively contribute to perception fallacy and eventually to harmful connotations used during the negotiations. From using the false traces (i.e. pointing out the unclear impact of the Losuo tributary dams in Lancang basin rather than hydro-meteorological effects), underling the irrefutable character of the operationalized EoE Study findings (i.e. proofing the compounding effects of Chinese mainstream dams without operational hydrological data) to showing the compassion for current water challenges (i.e. illustrating $R_{x 3}$ as defenceless victims and providing faith in changing the water insecurities risks by calling for non-reciprocal hydrological data sharing) or implying the false dilemma (e.g. over-focus on upstream mainstream dams with limited acknowledgement of the downstream water projects). Thus, rather than finding the "iron rule" in human-water interaction, we open the debate on how

450 to better understand the changing dynamics of the $R D$ over water science, how to conceptualize the politicization of water science and how to develop better fact-checking tools to improve the quality of the research inputs negatively affecting the transboundary water governance. 


\subsubsection{Comparison of the standard and alternative research procedures}

In the COVID-19 era, the pressure on a fast research process and medialization of research findings provide several benefits for the $R D$. More multi-stakeholders, particularly the civil society organizations in downstream countries may step into the negotiations, share their experience and provide valuable feedback about the current water-related challenges at the local level. The $A P$ is also more friendly towards the $R_{y 4}$ who may put less effort to provide relatively accurate research results for $R_{x l-3}$. Among other benefits of the $A P$ are diversifying the notification process through the MDM social network websites (i.e. Facebook and Twitter) and engaging the civil society into the hydrological data monitoring as the indirect control mechanism. While such acceleration of the research process may positively decentralize the research process (Bouleau, 2019; Haefner, 2016; Banks, Hulme and Edwards, 2014), the growing pressure from civil society on ensuring practical results and immediate structural changes may not necessarily enhance the $R D$ (Weng 2015; Besley and Nisbet, 2013). Perhaps, the biggest challenge presents the intervention of the $R_{y l-4}$ into the public media and political rhetoric escalation between $R_{x l}$ and $R_{x 2}$ that contribute to the $C F$. Unlike the $S P$ relying on the long peer-review process and other control mechanisms ensuring the high-quality of the research publications, the $A P$ is contributing to double standards in the $N$ and feeding the politicization of the $E$. While the $R_{y l-2}$ overlook the existing research from the $R_{y 3}$, criticize the lack of determination from the $R_{x 2-3}$ and marginalize the feedback from a plethora of $R_{y 4-5}$, the $R_{y l-2}$ continue to narrow the $D$ (e.g. leaving the MDM without external control, absence of dialogue with $R_{y 3}$, lack of high-impact publications) and leverage the $N$ (e.g. sharing speculations without robust evidence, using non-scientific jargon, absence of high-quality research inputs). Such example can be found in terms of the MRC $\left(R_{y 5}\right)$ before April 2020 when the MRC received a request to provide water level data from 1960 to 2019 but have not been contacted to review the draft or final version of the EoE Study (MRC, 2020c: 1, 3). Although $R_{y l}$ has the full right to not share any information about the ongoing research nor any obligation to consult the preliminary results, the $R_{y 5}$ has no authority to refute any hydrological study. In response, the $R_{y 5}$ published several reply papers (MRC, 2020a, 2020c) and presented research conclusions on the MDM websites (MRC, 2021a, 2021b, 2021c) rather than mediating the conflict of ideas alone.

The politicization of science is not necessarily bad and may serve as an "icebreaker" for putting new water challenges for further consideration in the political agenda. To date, the current $D$ is mainly focused on supporting "science without politics" (Madani and Shafiee-Jood, 2020; Hamilton et al., 2019; Levy et al., 2016; Troy et al., 2015; Savenije, Hoekstra and van der Zaag 2014), addressing the contemporary water challenges by highly sophisticated research innovations (Cuttita, 2018; Jessop, 2014) or simple low-cost solutions (Bouleau, 2019; Haefner, 2016; Banks, Hulme and Edwards, 2014). However, despite the multi-stakeholders are free to speculate and refute the current $N$ by all means, we believe that the current development pathways in the $A P$ brings more costs than benefits for the $R D$. The only exceptions present the $R_{y 4}$, particularly researchers from the Chulalongkorn and Aalto University discussing the benefits of the $S P$ and enhancing the $C O$ among $R_{y 4}$. A similar positive trend can be also found in terms of the $R_{y 3}$ who abandoned the $A P$ responses through media (Tian et al. 2020, Tian, Liu and Lu 2020, Lu 2020) and put more effort in SP (e.g. Hou et al., 2021; Lu et al. 2021; Wei et al., 2021; Hou et al., 2020, Li et al. 2021, Sun et al. 2019). 


\subsubsection{Contrast between compliance and conflict of ideas}

The actual gap between $R_{x l-3}$ and $R_{y l-5}$ present an inevitable conflict of interests in transboundary water management (Wei et al., 2020; Ert, Cohen-Amin and Dinar, 2019; Weber et al., 2011). Although the $R_{x 1-3}$ formally ensure national water security and decide which water issues will become part of the national agenda (Grünwald, 2018; Oosterloo, 2016; Cook and Bakker,

2012; Buzan, Weaver and Wilde, 1998), $R_{y 1-5}$ can influence the national water plans and affect the transboundary water governance. For $R_{y l-5}$, the faith in standard research procedures, plurality of technocratic views and comprehensive control mechanisms present a solid basis for examining the current water-related challenges and designing new water policies. Since April 2020, the EoE Study was used by the $R_{x l}$ as diplomatic leverage improving the transparency of the hydrological data and blaming Chinese water projects for amplifying the severe droughts in downstream countries (e.g. Pompeo, 2020; Stilwell, 2020a; Stillwell, 2020b; Price, 2021). However, without operational hydrological data from Chinese dams and excluding the left-bank tributaries (notably Ruak/Nam Mae Sai River, Nam Yawng River or Nam), determining the real impact of the upstream dams on the natural flow can be challenging. On the other hand, thanks to sophisticated visualization of the hydrological changes through the satellite images (Eyler and Weatherby, 2020), the non-scientific community was capable to understand complex hydrological changes without further explanation. Also, despite these efforts to provide simple hydrological models, no high-quality research inputs following the $S P$ nor lawsuit or mass protest actions were made in the name of the EoE Study. Surprisingly, regardless of the numerous statements from $R_{x I}$ that highly resonated in official and public media, there were very shallow official responses to the EoE Study from $R_{x 3}$, including from Thailand where the research was conceived (see Grünwald, Feng and Wang, 2021). This may indicate the lack of unity among multi-stakeholders but also the limited utility of the EoE Study findings in transboundary water governance. On the other hand, the EoE Study clearly demonstrated the true power of the politicized hydrological studies provided by third parties (Elbers and Arts, 2011; Hirsch, 2003) and the determination of the $R_{x l}$ to advance the existing water cooperation in hydrological data sharing.

Therefore, $R_{x I-5}$ are not apolitical and their capacity to be an arbiter for mediating the conflicts between multi-stakeholders is limited to the willingness of the $R_{y l-3}$ who may accept or deny the scientific recommendations (Pardini et al., 2021). In other words, no matter how accurate hydrological models are and what negative implications could present the proposed agenda for transboundary water governance, the legal responsibility still lies on the $R_{y 1-3}$ (Colloff, Grafton and Williams, 2021; Wester, Rap and Vargas, 2009; Weible, 2008). While both $R_{y 1}$ and $R_{y 2}$ demonstrated some determination for improving the transboundary water management and promoting further collaboration with China (Eyler and Weatherby, 2020; Van, 2020; Niseyi, 2020; Eyler, 2020), a qualitative asymmetry between hydrological studies (Michalska-Smith and Allesina, 2017), personal beliefs of scientists (see Kreps and Kriner, 2020; Lyengar and Massey, 2019; Petersen, Vincent and Westerling, 2019)

515 and anti-scientific movements are much bigger challenge for the $R D$. Hence, whenever $R_{y l}$ and $R_{y 2}$ are committed to actively "open a door to discussion" with multi-stakeholders (Eyler and Weatherby, 2020) and "find avenues for [closer] collaboration with China" (EWC, 2021: 22-23), finding the financially feasible, politically acceptable and administratively convenient solutions (Molle, Mollinga and Wester, 2009; Sivapalan and Blöschl, 2015) can be easily reversed by the $R_{x l-3}$. 


\subsubsection{Discourse practices and water narratives in socio-hydrology}

Unlike the $S P$ where various research articles, water reports and other high-quality inputs undergo multiple peer-review processes, the newspaper articles and other online speech acts published through the $A P$ are getting more popular due to the growing professionalization of the NGOs and integration of the public-science movements (see Banks, Hulme and Edwards, 2015; Bergner, 2010). However, neither numerous editors nor fact-checking tools are fast enough to simultaneously verify the research content (see Moreno-Gil, Ramon and Rodríguez-Martínez, 2021; Zhou and Zafarani, 2020; Kanozia, 2019; Pavleska et al., 2018; Bohannon, 2013; Colquhoun, 2011). Once the misinformation, overstatement or disinformation is published from $R_{y l-5}$, retrospective correcting of errors and retracting the inaccurate beliefs of popular narratives (Dickson, 1988) can be challenging. As showed in the adapted Baker's model applied on the EoE Study case study, the $R_{y l}$ attempt to identify how the Chinese dams are altering the natural flow (Bassist and Williams, 2020) significantly backfired. While closer collaboration with $R_{y 4-5}$ multi-stakeholders and providing additional hydrological monitoring through the MDM positively strengthen the $R D$, organizing more public-research meetings and other trainings along with the $R_{x 2}$ and $R_{y 2}$ (e.g. SC, 2021a; EWC, 2021; EJN, 2021; Keshap, 2021; SC, 2021a) only highlight the ineffectiveness of the applied research inputs in depoliticizing the water science. Another weakness of using the $A P$ over $S D$ present the rise of the anti-scientific movements and growing distrust among the $R_{x l-3}$. Since all of the $R_{y l}$ inputs were made outside of the $S D$ (Basist and Williams, 2021, 2020a, 2020b) and unilaterally co-developed by the $R_{y I}$ through the MDM (Basist et al., 2020), such content is more prone to politicizing the $E$ and confirming the prior beliefs without taking any responsibility for the published content.

To conclude, socio-hydrology like any other interdisciplinary scientific field struggle with a crisis of knowledge that does not necessary implicate the wisdom of how to underpin sustainable water management (Srinivasan, 2015: 787; Loucks, 2015: 4790; Sivapalan, Savenije and Blöschl, 2012: 1273). As we mentioned above, the politicization of science is a complicated process of re-considering existing water paradigms and vigorous capacity to test alternative interpretations of complex phenomena. With growing medialization and misinterpretation of science, it is highly rewarding to diversify research channels and put more pressure on reasonable scientific etiquette. Also, despite the standard research procedures may not be perfect, sharing the hydrological data and facilitating the $R D$ between scientists and non-scientists is a good start how to delimit the unconstructive water narratives and promote mutual trust between multi-stakeholders. However, trust among multistakeholders cannot be granted. It can be only earned by mutual respect, solidarity and patience in improving the accuracy of the predictive hydrological models (Jiménez et al. 2020; Head, 2017). While the quality of hydrological science may vary, we strongly believe that socio-hydrology may more effectively address these discrepancies and positively strengthen the conceptualization of the $R D$ through the $S D$ that is currently more viable than the $A D$.

\section{Disclosure statement}

No potential conflict of interest was reported by the authors. 
https://doi.org/10.5194/hess-2021-647

Preprint. Discussion started: 18 January 2022

(c) Author(s) 2022. CC BY 4.0 License.

\section{Acknowledgement}

This research was supported by the Yunnan Basic Research Programs (202101AT070185) and National Natural Science Foundation of China (41701626) as well as the Yunnan Graduate Case building program. We want to thank the editor and two reviewers for valuable comments improving the quality of the manuscript, and all honourable fathers who motivated us to make a better world.

\section{Author contribution}

WW, RG and FG conceived, designed, and supervised the research. All authors contributed to the writing of the manuscript.

\section{References}

Albrecht, F. Natural hazards as political events: framing and politicisation of floods in the United Kingdom. Environmental Hazards 20(1): 1-20, doi 10.1080/17477891.2021.1898926, 2021.

560 Altheide, D.L., Snow, R.P. Media Logic. Beverly Hills: Sage, 1979.

Ancker, J.S., Flanagin, A. A comparison of conflict of interest policies at peer-reviewed journals in different scientific disciplines. Science and Engineering Ethics 13(1): 147-157, doi 10.1007/s11948-007-9011-z, 2007.

Aspeitia, A. A. B. Whataboutism and Inconsistency. Argumentation 34(1): 433-447, doi 10.1007/s10503-020-09515-1, 2020. Atkins, E. Disputing the 'National Interest': The Depoliticization and Repoliticization of the Belo Monte Dam, Brazil. Water

565 11(1): 1-21, doi 10.3390/w11010103, 2019.

Baker, M. Is There a Reproducibility Crisis?. Nature 533(1): 7604, 2016.

Banks, N., Hulme, D., Edwards, M. NGOs, States, and Donors Revisited: Still Too Close for Comfort?. World Development 66, 707-718, doi 10.1016/j.worlddev.2014.09.028, 2015.

Baron, N. A Guide to Making Your Science Matter. Escape from the Ivory Tower. Washington: Island Press, 2010.

570 Basist A, Dinar A, Blankespooor B, Bachiochi D, Houba H. Use of Satellite Information on Wetness and Temperature for Crop Yield Prediction and River Resource Planning Climate Smart Agriculture. In. Lipper, L., McCarthy, N., Zilberman, D., Asfaw, S., Branca, G. (eds.), Climate Smart Agriculture, Cham: Springer, p. 77-104, 2018.

Basist, A., Carr, A., Eyler, B., Weatherby, C., Williams, C. Mekong Dam Monitor. Available at: https://www.stimson.org/project/mekong-dam-monitor/, 2020.

575 Basist, A., Williams, C. EOE Report on the Improvement of the Wetness Index in Discharge Models along the Upper Mekong River, 2021. available at: https://www.eyesonearth.org/single-post/eoe-report-on-the-improvement-of-the-wetness-index-in-dischargemodels-along-the-upper-mekong-river) 
https://doi.org/10.5194/hess-2021-647

Preprint. Discussion started: 18 January 2022

(c) Author(s) 2022. CC BY 4.0 License.
Hydrology and

Earth System

Sciences

Discussions

Basist, A., Williams, C. Monitoring the Quantity of Water Flowing Through the Mekong basin Through Natural (unimpeded) conditions. Bangkok: Lower Mekong Initiative Sustainable Infrastructure Partnership, 2020a.

Basist, A., Williams, C. EOE Report on the Improvement of the Wetness Index in Discharge Models along the Upper Mekong River. Eyes on Earth, 2020b.

Basist, A., Williams, C., Ross, T. F., Menne, M. J., Grody, N., Ferraro, R., Shen, S., Chang, A.T.C. Using the Special Sensor Microwave Imager to Monitor Surface Wetness. Journal of Hydrometeorology 2(3): 297-308, 2001.

585 Bergner, I. Internet communication and practices of scientists in the academic world. Ph.D. thesis, Fernuniversität Hagen, Hagen, Germany, 2010.

Besley, J.C., Nisbet, M. How Scientists View the Public, the Media and the Political Process. Public Understanding of Science 22(6): 644-659, doi 10.1177/0963662511418743, 2013.

Biba, S. China's 'old' and 'new' Mekong River politics: the Lancang-Mekong Cooperation from a comparative benefit-sharing

perspective. Water International 43(5): 622-641, doi 10.1080/02508060.2018.1474610, 2017.

Biba, S. China's Continuous Dam-building on the Mekong River. Journal of Contemporary Asia 42(4): 603-628, doi 10.1080/00472336.2012.712257, 2012.

Binh, D.V., Kantoush, S.A., Saber, M., Mai, N.P., Maskey, S., Phong, D.T., Sumi, T. Long-term alternations of flow regimes of the Mekong River and adaption strategies for the Vietnamese Mekong Delta. Journal of Hydrology: Regional Studies 32(1): 100742, 1-21, doi 10.1016/j.ejrh.2020.100742, 2020.

Blankespoor, B., Basist, A., Dinar, A., Dinar, S., Houba, H., Thomas, N. Assessing the Economic and Political Impacts of Climate Change on International River Basins using Surface Wetness in the Zambezi and Mekong Basins. Amsterdam: Tinbergen Institute Discussion Paper, TI 2014-005/II, 1-50, 2014.

Bohannon, J. Who's Afraid of Peer Review?. Science 342(1): 6164, doi 10.1126/science.342.6154.60, 2013.

600 Bolsen, T., Druckman, J.N. Countering the Politicization of Science. Journal of Communication 65(1): 745-769, doi 10.1111/jcom.12171, 2015.

Bouleau, G. Politicization of Ecological Issues. From Environmental Forms to Environmental Motives. London: ISTE, 2019. Brown, M.B. Politicizing science: Conceptions of politics in science and technology studies. Social Studies of Science 45(1): 3-30, doi: doi:10.1177/0306312714556694, 2015.

605 Buzan, B., Wæver, O., Wilde, J. Security: A New Framework for Analysis. Lynne Rienner: Boulder, USA, 1998.

Cambodia National Mekong Committee (CNMC). 52nd MRC JC and 25th MRC Dialogue Partners Meetings (September 1617, 2021). Available at: http://cnmc.gov.kh/cnmc/index.php/en/2021-09-17-03-10-00, 2021.

Cech, T. Principles of Water Resources. History, Development, Management and Policy. New York: Willey, 2010.

Center for Social Development Studies (CSDS). The Mekong, China, \& SE Asian Transitions Series-Mekong Dams: Debates 610 and the Politics of Evidence [Online, 29 April 2021]. Available at: https://www.csds- 
chula.org/activityandevents/2021/4/29/event-resources-the-mekong-china-amp-se-asian-transitions-series-mekong-damsdebates-and-the-politics-of-evidence-online-29-april-2021, 2021.

Center for Social Development Studies (CSDS). EVENT [RESOURCES]: The Mekong runs dry? Governance in transition: A close look at current rules and geopolitics at play. Available at: https://www.csds-

615 chula.org/activityandevents/2020/7/30/event-resources-the-mekong-runs-dry-governance-in-transition-a-close-look-atcurrent-rules-and-geopolitics-at-play, 2020a.

Center for Social Development Studies (CSDS). EVENT [RESOURCES]: Low Flows, Drought, Data and Geopolitics on the Mekong-Lancang [Bangkok, 6 August 2020]. Available at: https:/www.csds-chula.org/activityandevents/2020/8/7/eventresources-low-flows-drought-data-and-geopolitics-on-the-mekong-lancang-bangkok-6-august-2020, 2020b.

620 Center for Social Development Studies (CSDS). EVENT [RESOURCES]: Virtual Conference on Sustainable Development and the Future of the Mekong [Online, 27 October 2020]. Available at: https://www.csdschula.org/activityandevents/2020/10/28/cicp-virtual-conference-sustainable-development-future-of-mekong, 2020c.

Colloff, M.J., Grafton, R.Q., Williams, J. Scientific integrity, public policy and water governance in the Murray-Darling Basin, Australia. Australasian Journal of Water Resources 24(2): 1-20, doi 0.1080/13241583.2021.1917097, 2021.

625 Colquhoun, D. Publish-or-perish: Peer review and the corruption of science. Available at: https://www.theguardian.com/science/2011/sep/05/publish-perish-peer-review-science, 2011.

Cook, C., Bakker, K. Water security: Debating an emerging paradigm. Global Environmental Change 22(1): 94-102, doi 10.1016/j.gloenvcha.2011.10.011, 2012.

Cook, J., Ecker, U., Lewandowsky, S. Misinformation and How to Correct It. Emerging Trends in the Social and Behavioral 630 Sciences XX(1): 1-17, doi:10.1002/9781118900772.etrds0222, 2015.

Corredor, L. Open Letter to the Mekong River Commission. Available at: https://www.scientists4mekong.com/wpcontent/uploads/2017/03/Open-Letter-to-the-Mekong-River-Commission-Edited.pdf, 2017.

Cronin, R.P., Hamlin, T. Mekong Tipping Point: Hydropower Dams, Human Security and Regional Stability. Washington: The Henry L. Stimson Center, 2010.

635 Cuttita, P. Repoliticization through Search and Rescue? Humanitarian NGOs and Migration Management in the Mediterranean. Geopolitics 23: 632-660, doi 10.1080/14650045.2017.1344834, 2018.

de Zwart, F. Unintended but not unanticipated consequences. Theory and Society 44(1): 283-297, doi: 10.1007/s11186-0159247-6, 2015.

Di Baldassarre, G., Sivapalan, M., Rusca, M., Cudennec, C., Garcia, M., Kreibich, H., Konar, M., Mondino, E., Mård, J., 640 Pande, S., Sanderson, M.R., Tian, F., Viglione, A., Wei, J., Wei, Y., Yu, D.J., Srinivasan, V., Blöschl, G. Sociohydrology: Scientific Challenges in Addressing the Sustainable Development Goals. Water Resources Research 55(8): 6327-6335, doi 10.1029/2018WR023901, 2019. 
Di Baldassarre, G., Viglione, A., Carr, G., Kuil, L., Yan, K., Brandimarte, L., Blöschl, G. Debates - Perspectives on sociohydrology: Capturing feedbacks between physical and social processes. Water Resources Research 51(6): 4770-4781, doi 10.1002/2014WR016416, 2015.

Di Baldassarre, G., Viglione, A., Carr, G., Kuil, L., Salinas, J.L., Blöschl, G. Socio-hydrology: conceptualising human-flood interactions. Hydrology and Earth System Sciences 17(1): 3295-3303, doi 10.5194/hess-17-3295-2013, $2013 \mathrm{a}$.

Di Baldassarre, G., Kooy, M., Kemerink, J.S., Brandimarte, L. Towards understanding the dynamics behaviour of floodplains as human-water systems. Hydrology and Earth System Sciences 17(1): 3235-3244, doi 10.5194/hessd-10-3869-2013, $2013 \mathrm{~b}$.

Dickson, S. H. The 'golden mean' in journalism. Journal of Mass Media Ethics 3(1): 33-37, doi 10.1080/08900528809358307, 1988.

Dietz, T. Bringing values and deliberation to science communication. Proceedings of the National Academy of Sciences 110(3): 14081-14087, doi 10.1073/pnas.1212740110, 2013.

Druckman, J.N., Fein, J., Leeper, T.J. A source of bias in public opinion stability. American Political Science Review 106(2): 430-454, doi 10.1017/S0003055412000123, 2012.

Earle, A., Jägerskog, A., Öjendal, J. Transboundary Water Management. Principles and Practice. London. Earthscan, 2010.

Earth Journalism Network (EJN). Mekong data Journalism Fellowship. Available at: https://earthjournalism.net/opportunities/expired-opportunities/Mekong-Data-Journalism-Fellowship-2021-, 2020.

East-West Center (EWC). Indo-Pacific Conference on Strengthening Governance of Transboundary Rivers Report.

Available at:

https://www.eastwestcenter.org/system/tdf/private/riverconference_report_2020_final_web.pdf?file=1\&type=node\&id=3948 6, 2021.

Elbers, W., Arts, B. Keeping body and soul together: Southern NGOs' strategic responses to donor constraints. International Review of Administrative Sciences 77(4): 713-732, doi 10.1177/0020852311419388, 2011.

665 Elshafei, Y., Sivapalan, M., Tonts, M., Hipsey, M. R. 2014. A prototype framework for models of socio-hydrology: identification of key feedback loops and parameterisation approach. Hydrology and Earth System Sciences 18(1): 2141-2166, doi 10.5194/hess-18-2141-2014, 2014.

Embassy of the People's Republic of China in the Kingdom of Cambodia (PRC-ECA). Foreign Ministry Spokesman's Zhao Lijian Remarks. Available at: http://kh.china-embassy.org/eng/fyrth_3/t1813183.htm, 2020.

670 Embassy of the People's Republic of China in the Kingdom of Thailand (PRC-ET). Chinese Embassy Spokesperson's Remarks on Mekong-related Media Report Targeting China. Available at:

http://www.chinaembassy.or.th/eng/sgxw/t1678896.htm, 2019.

Embassy of the People's Republic of China in the Kingdom of Thailand (PRC-ET). 'China's Water Hegemony in Asia' or 'Shared Rivers, Shared Futures': Which?. Available at: http://www.chinaembassy.or.th/eng/ztbd/t1384905.htm, 2016. 
675 Embassy of the People's Republic of China in the United States of America (PRC-EUS). Foreign Ministry Spokesperson Geng Shuang's Regular Press Conference on April 21, 2020. Available at: http://www.chinaembassy.org/eng/fyrth/t1772006.htm, 2020.

Ert, E., Cohen-Amin, S., Dinar, A. The effect of issue linkage on cooperation in bilateral conflicts: An experimental analysis. Journal of Behavioral and Experimental Economics 79(1): 134-142, doi 10.1016/j.socec.2019.02.004, 2019. Human-Water System Research Approach. Water 9(12): 1-12, doi 10.3390/w9120933, 2017.

Eyler, B., Basist, A., Williams, C., Kwan, R., Weatherby, C. Consultative processes lead to more accurate monitoring of the Mekong from Eyes on Earth and the Stimson Center. Available at: https://www.stimson.org/2021/consultative-processes-leadto-more-accurate-monitoring-of-the-mekong-from-eyes-on-earth-and-the-stimson-center/, 2021.

685 Eyler, B, Basist, A., Carr, A., Williams, C. 2020a Mekong Dam Monitor: Methods and Processes. Available at: https://www.stimson.org/2020/mekong-dam-monitor-methods-and-processes/, 2020a.

Eyler, B, Basist, A., Carr, A., Williams, C. The struggle for the soul of the Mekong River. Available at: https://www.bangkokpost.com/opinion/opinion/1960339/the-struggle-for-the-soul-of-the-mekong-river, $2020 \mathrm{~b}$.

Eyler, B. Mekong Mainstream at Chiang Saen, Thailand (Golden Triangle) drops $>1$ meter in 48 hours as Jinghong Dam

690 upstream fills. Available at: https://www.planet.com/stories/mekong-mainstream-at-chiang-saen-thailand-golden-tXlhhVOaGg, 2021a.

Eyler, B. Sekong Be Dammed: Preparatory Construction of the Sekong A Dam in southern Laos. Available at: https://www.planet.com/stories/sekong-be-dammed-preparatory-construction-of-the-s-96ocbbSng, 2021 b.

Eyler, B. Science Shows Chinese Dams Are Devastating the Mekong. Available at:

695 https://foreignpolicy.com/2020/04/22/science-shows-chinese-dams-devastating-mekong-river/, 2020.

Eyler, B., Sun, Y. Discussing China's Dams on the Mekong. Available at: https://www.stimson.org/2020/discussing-chinasdams-on-the-mekong/, 2020.

Eyler, B., Weatherby, C. New Evidence: How China Turned off the Tap on the Mekong River. Available at: https://www.stimson.org/2020/new-evidence-how-china-turned-off-the-mekong-tap/, 2020.

700 Foreign Correspondents' Club of Thailand (FCCT). Mekong Update: New evidence of China's dam impacts, and why it matters. Available at: https://www.fccthai.com/events/mekong-update-new-evidence-of-chinas-dam-impacts-and-why-itmatters/, 2020.

Fox, C. A., Sneddon, C.S. Political Borders, Epistemological Boundaries, and Contested Knowledges: Constructing Dams and Narratives in the Mekong River Basin. Water 11(3): 413-431, doi 10.3390/w11030413, 2019.

705 Fritz, K G., Miller, D. Hypocrisy and the Standing to Blame. Pacific Philosophical Quarterly 99(1): 118-139, doi 10.1111/papq.12318, 2018. 
Ghoreishi, M., Razavi, S., Elshorbagy, A. Understanding Human Adaptation to Drought: Agent-Based Agriculture Water Demand Modeling in the Bow River Basin, Canada. Hydrological Science Journal 66(3): 389-407, doi 10.1080/02626667.2021.1873344, 2021.

710 Gonzales, P., Ajami, N. Social and Structural Patterns of Drought-Related Water Conservation and Rebound. Water Resources Research 53(12): 10619-10634, doi 10.1002/2017WR021852, 2017.

Grünwald, R., Feng, Y., Wang, W. Politicization of science in the Lancang-Mekong Basin: The Eyes on Earth Study. International Journal of Water Resources Development, 1-27, doi 10.1080/07900627.2021.1990025, 2021.

Grünwald, R., Feng, Y., Wang, W. Reconceptualization of the Transboundary Water Interaction Nexus (TWINS): approaches,

715 opportunities and challenges. Water International 45(5): 458-478, doi 10.1080/02508060.2020.1780854, 2020.

Grünwald, R., Wang, W., Feng, Y. Modified Transboundary Water Interaction Nexus (TWINS): Xayaburi Dam Case Study. Water 12(3): 1-18, doi: 10.3390/w12030710, 2020.

Grünwald, R. Lancang Mekong Cooperation: Present and Future of the Mekong River Basin. Journal of Political Science 23(1): 69-97, doi: 10.24040/politickevedy.2020.23.2.69-97, 2020.

Grünwald, R. Role of the Water Security in the International Relations: The Mekong River Basin Case Study (Unpublished $\mathrm{PhD}$. Thesis), 2018.

Haas, P. Epistemic Communities and International Policy Coordination. International Organizations 46(1): 1-35, doi 10.1017/S0020818300001442, 1992.

Haciyakupoglu, G., Hui, J. Y., Suguna, V. S., Leong, D., Rahman, M. F. B. A. Countering Fake News. A Survey of Recent 725 Global Initiatives. Policy Report, 2018.

Haefner, A. Negotiating for Water Resources. Bridging Transboundary River Basins. New York: Earthscan, 2016.

Hajer, M. The politics of environmental discourse: Ecological modernization and the policy process. Oxford: Clarendon Press, 1995.

Hamilton, S.H., Fu, B., Guillaume, J.H.A., Badham, J., Elsawah, S., Gober, P., Hunt, R.J., Iwanaga, T., Jakeman, A.J., Ames,

730 D.P., Curtis, A., Hill, M.C., Pierce, S.A., Zare, F. A framework for characterizing and evaluating the effectiveness of environmental modelling. Environmental Modelling and Software 118(1): 83-98. doi 10.1016/j.envsoft.2019.04.008, 2019. Hamm, J. A., L. M. PytlikZillig, M. N. Herian, A. J. Tomkins, H. Dietrich, and S. Michaels. Trust and intention to comply with a water allocation decision: the moderating roles of knowledge and consistency. Ecology and Society 18(4): 49, doi 10.5751/ES-05849-180449, 2013.

735 Han, P., Mea, S., An, H. P. Understanding Quality Energy-Related Infrastructure Development in the Mekong Subregion: Key Drivers and Policy Implications. ERIA Discussion Paper Series 363(1): 1-42, 2021.

Head, B.W. Water policy - Evidence, learning and the governance of uncertainty. Policy and Society 2(1): 171-180, doi 10.1016/j.polsoc.2010.03.007, 2017. 
Heis, A., Vaddhanphuti, C. Thai Baan Methodology and Transdisciplinarity as Collaborative Research Practices: Common

Ground and Divergent Directions. Austrian Journal of South-East Asian Studies 13(2): 211-228, doi 10.14764/10.ASEAS-, 2020 .

Hirsch, J. The States New Clothes: NGOS and the Internationalization of States. Politica y Cultura 20(1): 7-2, 2003.

Hirsch, P. The shifting regional geopolitics of Mekong dams. Political Geography 51(1): 53-74, doi 0.1016/j.polgeo.2015.12.004, 2016.

745 Hmielowski, J.D., Feldman, L., Myers, T.A., Leiserowitz, A., Maibach, E. An attack on science? Media use, trust in scientists, and perceptions of global warming. Public Understanding of Science 23(7): 866-833, doi 10.1177/0963662513480091, 2013. Hou, S., Tian, F., Lu, Y., Ni, G., Lu, H., Liu, H., Wei, J. Flood control effect of joint operation of reservoirs in LancangMekong River basin (澜沧江-涺公河流域水库联合调度防洪作用). Advances in Water Science 32(1): 68-78, 2021.

Hou, S., Tian, F., Ni, G. Analysis of existing problems in studies on sediment production, transport and reservoir containment in Lancang-Mekong River Basin (澜沧江-湄公河流域产输沙和水库拦沙研究存在问题分析). Advances in Water Science 34(1): 619-628, 2021.

Hutjens, P., Yasuda, Y., Swain, A., De Man, R., Magsig, B.O., Islam, S. The Multi-track Water Diplomacy Framework. A Legal and Political Economy Analysis for Advancing Cooperation over Shared Waters. Hague: The Hague Institute for Global Justice, 2016.

International Centre for Environmental Management (ICEM). Strategic Environment Assessment of Hydropower on the Mekong Mainstream. Final Report. Available at: https://icem.com.au/documents/envassessment/mrc_sea_hp/SEA_Final_Report_Oct_2010.pdf, 2010.

Jansen, S. C., Martin, B. The Streisand Effect and Censorship Backfire. International Journal of Communication 9(1): 656671, doi 10.1177/0894439309336943, 2015.

760 Jasanoff, S. S. Contested Boundaries in Policy-Relevant Science. Social Studies of Science 17(2): 195-230. doi:10.1177/030631287017002001, 1987.

Jessop, B. Repoliticising depoliticization: theoretical preliminaries on some responses to the American fiscal and Eurozone debt crises. Policy Politics 42(1): 207-223, doi 10.1332/030557312X655864, 2014.

Jiménez, A., Saikia, P., Giné, R., Avello, P., Leten, J., Lymer, B.L., Schneider, K., Ward, R. Unpacking Water Governance:

765 A Framework for Practitioners. Water 12(1): 1-21, doi 10.3390/w12030827, 2020.

Kallio, M. Link between Chinese dams \& Mekong drought?. Aalto University. Available at: https://wdrg.aalto.fi/link-betweenchinese-dams-mekong-drought/, 2020.

Kallio, M., Fallon, A. Critical Nature: Are China's dams on the Mekong causing downstream drought? The importance of scientific debate. Available at: https://www.csds-chula.org/publications/2020/4/28/critical-nature-are-chinas-dams-on-themekong-causing-downstream-drought-the-importance-of-scientific-debate, 2020. 
Kanozia, R. Analysis of Digital Tools and Technologies for Debunking Fake News. Journal of Content, Community \& Communication 9(1): 114-122, doi 10.31620/JCCC.06.19/16, 2019.

Karr, J.R. When Government Ignores Science, Scientists Should Speak Up. Bioscience 56(4): 287-288, doi 0.1641/00063568(2006)56[287:WGISSS]2.0.CO;2, 2006.

775 Kasymov, S. Water Resource Disputes: Conflict and Cooperation in Drainage Basins. International Journal of World Peace 28(3): 81-110, 2011

Kelly, J., Sadeghieh, T., Adeli, K. Peer review in scientific publications: benefits, critiques, \& a survival guide. The Journal of the International Federation of Clinical Chemistry and Laboratory Medicine 25(3): 227-243, 2014.

Keovilignavong, O., Nguyen, T.H., Hirsch, P. Reviewing the causes of Mekong drought before and during 2019-20. International Journal of Water Resources Development, doi: 10.1080/07900627.2021.1967112, 2021.

Kerckhove, D.T., Rennie, M.D., Cormier, R. Censoring government scientists and the role of consensus in science advice. EMBO Reports 16(3): 263-266, doi 10.15252/embr.201439680, 2015.

Keshap, A. Remarks at the Mekong-U.S. Partnership Track 1.5 Policy Dialogue Opening Plenary. Available at: https://www.state.gov/remarks-at-the-mekong-u-s-partnership-track-1-5-policy-dialogue-opening-plenary/, 2021

785 Ketelsen, T., Sawdon, J., Räsärenen, T. Monitoring the Quantity of water flowing through the Upper Mekong Basin under natural (unimpeded) conditions, 2020.

Kircherr, J. Strategies of Successful Anti-Dam Movements: Evidence from Myanmar and Thailand. Society \& Natural Resources 31(2): 166-182, doi 10.1080/08941920.2017.1364455, 2019.

Konar, M., Garcia, M., Sanderson, M.R., Yu, D.J., Sivapalan, M. Expanding the Scope and Foundation of Sociohydrology as 790 the Science of Coupled Human-Water Systems. Water Resources Research 55(2): 874-887. doi 10.1029/2018WR024088, 2018.

Kreps, S.E., Kriner, D.L. Model uncertainty, political contestation and public trust in science: Evidence from the COVID-19 pandemic. Science Advances 6(43): 1-12, doi 10.1126/sciadv.abd4563, 2020.

Lancang-Mekong Water Cooperation Information Platform (LMWCIP). Discussion on Hydrological Conditions Held with 795 Consensus of Strengthening Lancang-Mekong Water Cooperation. LMWCIP. Available at: http://www.lmcwater.org.cn/dynamic news/202103/t20210316_164074.html, 2021a.

Lancang-Mekong Water Cooperation Information Platform (LMWCIP). Notification of Hydrological Information on Lancang $\begin{array}{lllll}\text { River } \quad \text { (January } & \text { 2021). } & \text { LMWCIP. }\end{array}$ www.lmcwater.org.cn/water_information/regulation_information/202101/t20210105_163831.html, 2021b.

800 Lancang-Mekong Water Cooperation Information Platform (LMWCIP). Notification of Operation Information of Jinghong Hydropower Station on Lancang River (July 30, 2021). Available at: http://www.lmcwater.org.cn/water_information/regulation_information/202108/t20210802_164635.html, 2021c. 
https://doi.org/10.5194/hess-2021-647

Preprint. Discussion started: 18 January 2022

(c) Author(s) 2022. CC BY 4.0 License.

Lancang-Mekong Water Resources Cooperation (LMWCIP). Notification of Hydrological Information on Lancang River

(December 27 ,

2019).

Available

at:

805

www.lmcwater.org.cn/water_information/regulation_information/202008/t20200824_162706.html, 2019.

Lane, S.N. Acting, predicting and intervening in a socio-hydrological world. Hydrology and Earth System Sciences 18(3): 927-952, doi 10.5194/hess-18-927-2014, 2014.

Latour, B. When things strike back: a possible contribution of "science studies" to the social sciences. British Journal of Sociology 51(1): 107-123, doi 10.1111/j.1468-4446.2000.00107.x, 2000.

810 Lee Kuan Yew School of Public Policy (LKY). ASEAN Faces the Future: What to Expect from the 27th ASEAN Regional Forum, 2020.

Levy, M.C., Garcia, M., Blair, P., Chen, X., Gomes, S.L., Gower, D.B., Grames, J., Kuil, L., Liu, Y., Marston, L., McCord, P.F., Roobavannan, M., Zeng, R. Wicked but worth it: student perspectives on socio-hydrology. Hydrological Processes 30(9): 1467-1472, doi 10.1002/hyp.10791, 2016.

815 Li, Y., Wang, J., Tang, X., Luo, X., Tan, X., Wang, G. Characteristics of Runoff Variation and Seasonal Pattern of LancangMekong River in the Context of Environment Change (变化环境下澜沧江一湄公河流域径流演变及年内分配特征). Research of Soil and Water Conservation 28(1): 141-148, 2021.

Lim, C. Checking how fact-checkers check. Research and Politics 0(1): 1-7, doi 10.1177/2053168018786848, 2018.

Lorenz, S., Dessai, S., Paavola, P., Forster, P.M. The communication of physical science uncertainty in European National

820 Adaptation Strategies. Climate Change 132(1): 143-155, doi 0.1007/s10584-013-0809-1, 2013.

Loucks, D.P. Debates-Perspectives on socio-hydrology: Simulating hydrologic-human interactions. Water Resources Research 51(6): 4789-4794, doi:10.1002/2015WR017002, 2015.

Louhiala-Salmien, L., Kankaanranta, A. Language as an issue in international internal communication: English or local language? If English, what English?. Public Relations Review 38(2): 262-269, doi, 10.1016/j.pubrev.2011.12.021, 2012.

$825 \mathrm{Lu}, \mathrm{X}$. "Drought in the Lower reaches of the Lancang River caused by China's exploitation of water resources" is a false proposition (“中国开发澜沧江水资源导致下游干旱”是一个伪命题). Available at: http://cn.lmcwater.org.cn/authoritative_opinion/expert_commentary/202008/t20200831_162815.html, 2020.

Lu, X., Li, S., Kummu, M., Padawangi, R., Wang, J. Observed changes in the water flow at Chiang Saen in the lower Mekong: Impacts of Chinese dams?. Quaternary International 336(1): 145-157, doi 10.1016/j.quaint.2014.02.006, 2014.

830 Lu, Y., He, D., He, K., Yuan, X. Analysis and calculation of water consumption of hydropower plants in Lancang-Mekong River basin (澜沧江-涺公河水电站单位发电耗水量分析计算). Advances in Water Science 29(1): 415-423, 2018.

Lu, Y., Tian, F., Guo, L., Borzì, I., Patil, R., Wei, J., Liu, D., Wei, Y., Yu, D.J., Sivapalan, M. Socio-hydrologic modelling of the dynamics of cooperation in the transboundary Lancang-Mekong River. Hydrology and Earth System Science 25(4): 18831903, doi 10.5194/hess-25-1883-2021, 2021. 
835 Lu, Y., Tian, F., Guo, L., Borzì, I., Patil, R., Wei, J., Liu, D., Wei, Y., Yu, D. J., Sivapalan, M. Socio-hydrologic modelling of the dynamics of cooperation in the transboundary Lancang-Mekong River. Hydrology and Earth System Sciences 25(1): 18831903, doi 10.5194/hess-25-1883-2021, 2021.

Lupia, A. Communicating science in politicized environments. Proceedings of the National Academy of Sciences of the United States of America 110(3): 14048-14054, doi 10.1073/pnas.1212726110, 2013.

840 Lyengar, S., Massey, D. S. Scientific communication in a post-truth society. Proceedings of the National Academy of Sciences 116(16): 7656-7661, doi 10.1073/pnas.1805868115, 2019.

Madani, K., Majid, S.J. Socio-Hydrology: A New Understanding to Unite or a New Science to Divide?. Water 12(7): 1-26, doi 10.3390/w12071941, 2020.

Martin, C., MacDonald, B.H. Using interpersonal communication strategies to encourage science conversations on social media. PLoS ONE 15(11): e0241972, doi 10.1371/journal.pone.0241972, 2020.

Martinson, B.C. Give researchers a lifetime word limit. Nature 550, 303. doi 10.1038/550303a, 2017.

Massuel, S., Riaux, J., Molle, F., Kuper, M., Ogilvie, A., Collard, A.L., Leduc, C., Barreteau, O. Inspiring a Broader SocioHydrological Negotiation Approach With Interdisciplinary Field-Based Experience. Water Resources Research 54: 25102522, doi 10.1002/2017WR021691, 2018.

850 Matthews, N., Geheb, K. Hydropower Development in the Mekong Region: Political, socio-economic and environmental perspectives. New York: Routledge, 2015.

Mayeda, A.M., Boyd, A.D. Factors influencing public perceptions of hydropower projects: A systematic literature review. Renewable and Sustainable Energy Reviews 121, 109713, doi 10.1016/j.rser.2020.109713, 2020.

McCreary, S.T., Gamman, J.K., Brooks, B. Redefining and Testing Joint Fact-Finding for Environmental Dispute Resolution:

855 Ten Years of Success. Mediation Quarterly 18(4): 329-348, 10.1002/crq.3890180403, 2002.

Mekong Dam Monitor Facebook (MDM-F). Update for Week of March 22-28, 2021. Available at:

https://www.facebook.com/mekongdammonitor/posts/157966442861482), 30 March, 2021a.

Mekong Dam Monitor Facebook (MDM-F). Here's a post from Rak Chiang Khong Convservation group. Available at: https://www.facebook.com/mekongdammonitor/posts/157212269603566, 29 March, $2021 \mathrm{~b}$.

860 Mekong Dam Monitor Facebook (MDM-F). Eyes on Earth recently identified a bias in the input SSMI data. Available at: https://www.facebook.com/mekongdammonitor/posts/174623914529068, 28 April, 2021c.

Mekong Dam Monitor Facebook (MDM-F) Thanks John Roberts for confirming. Available at: https://www.facebook.com/mekongdammonitor/posts/171877691470357, 23 April, $2021 \mathrm{~d}$.

Mekong Dam Monitor Facebook (MDM-F). Understanding China's new Mekong data portal. Available at: 865 https://www.facebook.com/mekongdammonitor/posts/111754390816021, 30 December, 2020.

Mekong Dam Monitor Twitter (MDM-T). What China's state media won't tell you. Available at: https://twitter.com/MekongMonitor/status/1391925226338983938, 11 May, 2021a. 
Mekong Dam Monitor Twitter (MDM-T). Alert: Jinghong Dam release leads to .5m rise in \#Mekong mainstream levels over next 48-72 hrs in Chiang Rai. Available at: https://twitter.com/MekongMonitor/status/1378024816079482883, 3 April, 2021 b.

Mekong Dam Monitor Twitter (MDM-T) Over the last 24 hours, \#Mekong river levels in the Golden Triangle and along the Myanmar/Laos border increased 2 meters. Available at: https://twitter.com/MekongMonitor/status/1417904644848852999, 22 July, 2021c.

Mekong Dam Monitor Twitter (MDM-T). \#Vietnam's government pledges cooperation with the \#Mekong Dam Monitor. \#mekongmonitor. Available at: https:/twitter.com/MekongMonitor/status/1339649902008217602, 18 December, 2020.

875 Mekong River Commission (MRC). Twenty-fifth dialogue meeting of the MRC Joint Committee. Available at: https://www.facebook.com/mrcmekong/posts/4520804041275027, $2021 \mathrm{a}$.

Mekong River Commission (MRC). Mekong drops to "worrying" levels, some sections turning blue-green". Available at: https://www.mrcmekong.org/news-and-events/news/pr002-12022021/, 2021b.

Mekong River Commission (MRC). Near-Real Time Hydrometeorological Monitoring. Available:

880 https://monitoring.mrcmekong.org/, 2021c.

Mekong River Commission (MRC). Mekong River Basin Monitoring Tools. Available at: https://www.mrcmekong.org/newsand-events/news/pr-20210728/, 2021d.

Mekong River Commission (MRC). MRC Secretariat CEO Urges Deeper Engagement During Friends of the Mekong Ministerial Meeting. Available at: https://www.mrcmekong.org/news-and-events/news/pr-20210809/, 2021e.

885 Mekong River Commission (MRC). Mekong River levels see slight increase, monsoon rains to begin earlier. Available at: https://www.mrcmekong.org/news-and-events/news/pr003-22022021/, 2021f.

Mekong River Commission (MRC). Mekong water levels to drop due to power grid maintenance in China. Available at: https://www.mrcmekong.org/news-and-events/news/pr001-06102021/, 2021g.

Mekong River Commission (MRC). Understanding the Mekong River's hydrological conditions: A brief commentary note on

890 the "Monitoring the Quantity of Water Flowing Through the Upper Mekong Basin Under Natural (Unimpeded) Conditions' study by Alan Basist and Claude Williams (2020). Vientiane: Mekong River Secretariat, 2020a.

Mekong River Commission (MRC). Hydrological Conditions in the Lower Mekong River Basin in January-July 2020. Vientiane: Mekong River Secretariat, 2020 b.

Mekong River Commission (MRC). Minutes of twenty-fourth dialogue meeting of the MRC Joint Committee. Vientiane:

895 Mekong River Secretariat, 2020c.

Mekong River Commission (MRC). MRC Secretariat, LMC Water Center ink first MOU for better upper-lower Mekong management. Available at: http://www.mrcmekong.org/news-and-events/news/mrc-secretariat-lmc-water-center-ink-firstmou-for-better-upper-lower-mekong-management/), 2019a. 
Mekong River Commission (MRC). Water flow from China's Jinghong station to fluctuate, but no major impact is expected. Available at: http://www.mrcmekong.org/news-and-events/news/water-flow-from-chinas-jinghong-station-to-fluctuate-butno-major-impact-is-expected/, 2019b.

Mekong River Commission (MRC). Hydrological Impacts of the Lancang Hydropower Cascade on Downstream Extreme Events. Vientiane: Mekong River Secretariat, 2019c.

Mekong River Commission (MRC). The Council Study. The Study on the Sustainable Management and Development of the Mekong River Basin including Impacts of Mainstream Hydropower Projects, 2017.

Melsen, L.A., Vos, J., Boelens, R. What is the role of the model in socio-hydrology? Discussion of "Prediction in a sociohydrological world". Hydrological Sciences Journal 63(9): 1435-1443. doi 10.1080/02626667.2018.1499025, 2018.

Michalska-Smith, M.J., Allesina, S. And, not or: Quality, quantity in scientific publishing. PLoS ONE 12(6): e0178074, doi 10.1371/journal.pone.0178074, 2017.

910 Ministry of Foreign Affairs of the People's Republic of China (MOFA PRC). Foreign Ministry Spokesperson Hua Chunying's Regular Press Conference on December 1, $2020 \quad$ (available at: https://www.fmprc.gov.cn/eng/xwfw_665399/s2510_665401/2511_665403/202012/t20201207_693521.html, 2021a.

Ministry of Foreign Affairs of the People's Republic of China (MOFA PRC). Joint Statement on Enhancing Sustainable Development Cooperation of the Lancang-Mekong Countries. Available at:

915 https://www.fmprc.gov.cn/mfa_eng/wjdt_665385/2649_665393/202106/t20210609_9170566.html, 2021b.

Ministry of Foreign Affairs of the People's Republic of China (MOFA PRC). Vice Foreign Minister Luo Zhaohui Attends the Inauguration Ceremony of the Lancang-Mekong Water Resources Cooperation Information Sharing Platform's Website. Available at: https://www.fmprc.gov.cn/eng/wjbxw/202012/t20201203_465628.html, 2020a.

Ministry of Foreign Affairs of the People's Republic of China (MOFA PRC). Foreign Ministry Spokesperson Wang Wenbin's

Regular Press Conference on December 14, 2020. Available at:
https://www.fmprc.gov.cn/mfa_eng/xwfw_665399/s2510_665401/2511_665403/202112/t20211214_10469658.html, 2020b. Ministry of Foreign Affairs of the People's Republic of China (MOFA PRC). The Fifth Lancang-Mekong Cooperation Foreign Ministers' Meeting was in https://www.fmprc.gov.cn/mfa_eng/wjb_663304/zzjg_663340/yzs_663350/gjlb_663354/2747_663498/2749_663502/20200 925 2/t20200222_519234.html, 2020c.

Mirumachi, N. Transboundary Water Politics in the Developing World. New York: Routledge, 2015.

Molle, F., Foran, T., Käkonen, M. Contested waterscapes in the Mekong Region: Hydropower, Livelihoods and Governance. London: Earthscan, 2009.

Molle, F., Mollinga, P.P., Wester, P. Hydraulic Bureaucracies and the Hydraulic Mission: Flows of Water, Flows of Power. 930 Water Alternative 3(2): 328-349, 2009. 
Mollinga, P.P. Water, Politics and Development: Framing a Political Sociology of Water Resources Management. Water Alternatives 1(1): 7-23, 2008.

Moreno-Gil, V., Ramon, X., Rodríguez-Martínez, R. Fact-Checking Interventions as Counteroffensives to Disinformation Growth: Standards, Values, and Practices in Latin American and Spain. Media and Communication 9(1): 251-263, doi 935 10.17645/mac.v9i1.3443, 2021.

Morgan, M., Collins, W.B., Sparks, G.G., Welch, J.R. Identifying Relevant Anti-Science Perceptions to Improve ScienceBased Communication: The Negative Perceptions of Science Scale. Journal of Social Science 7(4): 1-18, doi 10.3390/socsci7040064, 2018.

Mutz, D.C. Mass Media and the Depoliticization of Personal Experience. American Journal of Political Science 36(2): 483$940 \quad 508,1992$.

Neff, M.W. How Academic Science Gave its Soul to the Publishing Industry. Issues in Science and Technology 36(2): 35-43. Niseyi, S.P. More Transparency and Cooperation Needed for the Mekong River to Survive. Cambodianess. Available at: https:/cambodianess.com/article/more-transparency-and-cooperation-needed-for-the-mekong-river-to-survive, 2020.

Nüsser, M. Socio-hydrology: A New Perspective on Mountain Waterscapes at the Nexus of Natural and Social Processes.

945 Mountain Research and Development 37(4): 518-520, doi 10.1659/MRD-JOURNAL-D-17-00101.1, 2017

Octavianti, T., Charles, K. De- and re-politicisation of water security as examined through the lens of the hydrosocial cycle: The case of Jakarta's sea wall plan. Water Alternatives 12(3): 1017-1037, 2019.

Oosterloo, K. Conceptualizing the politicization of transboundary water governance. Presented at Nairobi Conference on Earth Systems Governance, Nairobi, Kenya, 7-9 December, 2016.

950 Pardini, R., Bertuol-Garcia, D., Araújo, B.D., Mesquita, J.P., Murer, B.M., Pônzio, M.C., Ribeiro, F.S., Rossi, M.L., Prado, P.I. COVID-19 pandemic as a learning path for grounding conservation policies in science. Perspectives in ecology and conservation 19(5): 1-6, doi 10.1016/j.pecon.2021.02.009, 2021.

Pavleska. T., Školkay, A., Zankova, B., Ribeiro, N., Bechmann, A. Performance analysis of fact-checking organizations and initiatives in Europe: a critical overview of online platforms fighting fake news. European Integration and Democracy Series 955 Social Media and Convergence 6(1): 1-29, 2018.

Peters, H.P. Gap between science and media revisited: Scientists as public communicators. PNAS 110(3): 14102-14109, doi 10.1073/pnas.1212745110, 2013.

Petersen, A.M., Vincent, E.M., Westerling, A.L. Discrepancy in scientific authority and media visibility of climate change scientists and contrarians. Nature Communications 10, 3502, doi 10.1038/s41467-019-09959-4, 2019.

960 Petr, M., Vacchiano, G., Thom, D., Mairota, P., Kautz, M., Goncalves, L.M.S., Yousefpour, R., Kaloudis, S., Reyer, C.P.O. Inconsistent recognition of uncertainty in studies of climate change impacts on forests. Environmental Research Letters 14, 113003, doi 10.1088/1748-9326/ab4670, 2019. 
Pielke, R.A. The Honest Broker: Making Sense of Science in Policy and Politics. Cambridge: Cambridge University Press, 2007.

965 Pielke, R.A. When scientists politicize science: making sense of controversy over the Skeptical Environmentalist. Environmental Science \& Policy 7(1): 405-417, doi 10.1016/j.envsci.2004.06.004, 2004.

Pompeo, M. R. The United States and ASEAN Are Partnering to Defeat COVID-19, Build Long-Term Resilience, and Support Economic Recovery. Available at: https://2017-2021.state.gov/the-united-states-and-asean-are-partnering-to-defeatcovid-19-build-long-term-resilience-and-support-economic-recovery/index.html, 2020.

Post, S., Ramirez, N. Politicized Science Communication: Predicting Scientists' Acceptance of Overstatements by their Knowledge Certainty, Media Perceptions, and Presumed Media Effects. Journalism \& Mass Communication Quarterly 95(4): 1150-1170, doi 10.1177/1077699018769668, 2018.

Price, N. Supporting a healthy, Sustainable Mekong River. U.S. Department of the State. Available at: https://www.state.gov/supporting-a-healthy-sustainable-mekong-river, 2021.

Roobavannan, M., van Emmerik, T.H.M., Elshafei, Y., Kandasamy, J., Sanderson, M., Vigneswaran, S., Pande, S., Sivapalan, M. Norms and Values in Socio-Hydrological Models. Hydrology and Earth System Sciences 22(2): 1337-1349, doi 10.5194/hess-22-1337-2018, 2018.

Rowlands, I., Nicholas, D., Russell, B., Canty, N., Watkinson, A. Social media use in the research workflow. Learned Publishing, 24(3): 183-195, doi 10.1087/20110306, 2011.

980 Sarewitz, D. Science can’t solve it. Nature 522: 413-414, doi 10.1038/522413a, 2015.

Sarewitz, D. The pressure to publish pushes down quality. Nature 533(1): 147-147, doi 10.1038/533147a, 2016.

Savenije, H.H.G., Hoekstra, A.Y., van der Zaag, P. Evolving Water Science in the Anthropocene. Hydrology and Earth System Sciences 18(1): 319-332, doi 0.5194/hess-18-319-2014, 2014.

Schmeier, S. Governing International Watercourses. River Basin Organizations and the sustainable governance of internationally shared rivers and Lakes. New York: Routledge, 2013.

Scientists for the Mekong (S4M). The Lao Hydropower group \#blocked us. Available at: https://www.facebook.com/scientists4mekong/posts/1655522064633447, 2021a.

Scientists for the Mekong (S4M). "Depths of China's Hydropolitics: the Hydropower Development in the Mekong River Basin". Available at: https://www.facebook.com/scientists4mekong/posts/1107665326085793, 2021b.

990 Seidl, R., Barthel, R. Linking scientific disciplines: hydrology and social sciences. Journal of Hydrology 550(1): 441-452, doi 10.1016/j.jhydrol.2017.05.008, 2017.

Sivapalan, M., Blöschl, G. Time scale interactions and the coevolution of humans and water. Water Resources Research 51(9): 6988-7022, doi: 10.1002/2015WR017896, 2015.

Sivapalan, M., Savenije, H.H.G., Blöschl, G. Socio-hydrology: A new science of people and water. Hydrological Processes 995 26(8): 1270-1276, doi 10.1002/hyp.8426, 2012. 
Sneddon, C., Fox, C. Rethinking transboundary waters: A critical hydropolitics of the Mekong basin. Political Geography 25(2): 181-202, doi 10.1016/j.polgeo.2005.11.002, 2006.

Sneddon, C.S., Magilligan, F.J., Fox., C.A. Science of the dammed: Expertise and knowledge claims in contested dam removals. Water Alternatives 10(3): 677-696, 2017.

1000 Spruijt, P., Knol, A.B., Vasileiadou, E., Devilee, J., Lebret, E., Petersen, A.C. Roles of scientists as policy advisers on complex issues: A literature review. Environmental Science \& Policy 40(1): 16-25, doi 10.1016/j.envsci.2014.03.002, 2014.

Srinivasan, V., Sanderson, M., Garcia, M., Konar, M., Blöschl, G., Sivapalan, M. Prediction in a socio-hydrological world. Hydrological Sciences Journal 62(3): 338-345, doi 10.1080/02626667.2016.1253844, 2016.

Srinivasan, V. Reimagining the past - use of counterfactual trajectories in socio-hydrological modelling: the case of Chennai,

1005 India. Hydrological Sciences Journal 19(1): 785-801, doi 10.5194/hess-19-785-2015, 2015.

State Council of the People's Republic of China (SCPRC). Premier Li attends GMS Meeting. Available at:

http://english.www.gov.cn/premier/news/202109/09/content_WS6139fd94c6d0df57f98dff08.html, 2021.

State Council of the People's Republic of China (SCPRC). Speech by Premier Li Keqiang at the third Lancang-Mekong Cooperation Leaders' Meeting. Available at:

1010 http://english.www.gov.cn/premier/speeches/202008/25/content_WS5f4448cac6d0f7257693ae42.html, 2020.

Stilwell, D.R. Special Briefing with David R. Stilwell, Assistant Secretary of State for the Bureau of East Asian and Pacific Affairs. Available at: https://2017-2021.state.gov/special-briefing-with-david-r-stilwell-assistant-secretary-of-state-for-thebureau-of-east-asian-and-pacific-affairs/index.html, 2020a.

Stilwell, D.R. The Mekong River, Mekong Sovereignty, and the Future of Southeast Asia. Available at:

1015 https://th.usembassy.gov/remarks-david-stilwell-assistant-secretary-at-indo-pacific-conference-on-strengtheningtransboundary-river-governance/, 2020b.

Stillwell, D.R. The Mekong-U.S. Partnership: Why the Mekong Region Matters to the United States, ASEAN, and the IndoPacific. Journal of Greater Mekong Studies 4(1): 11-15, 2020c.

Stimson Center (SC). Mekong-U.S. Partnership Track 1.5. Policy Dialogue Opening Plenary. Available at: https://www.stimson.org/event/mekong-u-s-partnership-track-1-5-policy-dialogue/, 2021a.

Stimson Center (SC). Alerts and Advisories. Stimson Center. Available at: https://www.stimson.org/2021/mekong-dammonitor-alerts-and-advisories/, $2021 \mathrm{~b}$.

Stimson Center (SC). A New Day for the Mekong: Launch of the Mekong Dam Monitor. Stimson Center (available at: https://www.stimson.org/event/launch_of_the_mekong_dam_monitor/, 2020a.

1025 Stimson Center (SC). New: Mekong Dam Monitor Brings Unprecedented Transparency to Basin-Wide Dam Operations. Stimson Center. Available at: https://www.stimson.org/2020/new-mekong-dam-monitor-brings-unprecedented-transparencyto-base-wide-dam-operations/, $2020 \mathrm{~b}$. 
Sun, Z., Chen, Z., Deng, Z., Dai, Y., Xu, D. Relation between sediment mass flux and volume runoff under natural condition of Lancang River (澜沧江自然条件下输沙质量通量与体积径流量的关系). Journal of Zhejiang University 53(1): 932-939, 10.14042/j.cnki.32.1309.2018.03.014, 2019.

Swann, W. B., Bosson, J.K. Identity Negotiation: A Theory of Self and Social Interaction. In. John, O.P., Robins, R.W., Pervin, L.A. (eds.), Handbook of Personality: Theory and Research, 3rd Edition, New York: Guilford Press, p. 448-471, 2008.

Thu, H.N., Wehn, U. Data sharing in international transboundary context: The Vietnamese perspective on data sharing in the Lower Mekong Basin. Journal of Hydrology 536(1): 351-364, doi: 10.1016/j.hydrol.2016.02.035, 2016.

1035 Tian, F., Liu, H., Hou, S., Li, K., Lu, H., Ni ,G., Mu, X., Bai, Y. Drought Characteristics of Lancang-Mekong River Basin and the Impacts of Reservoir Regulation on Streamflow. Tsinghua University, 2020.

Tian, F., Liu, H., Lu, H. Trust key to Lancang-Mekong Cooperation. China Daily. Available at: http://www.chinadailyasia.com/article/141177, 2020.

Troy, T.J., Konar, M., Srinivasan, V., Thompson, S. Moving Sociohydrology Forward: A Synthesis across Studies.

1040 Hydrology and Earth System Sciences 19(8): 3667-3679. doi 10.5194/hess-19-3667-2015, 2015.

U.S. Embassy \& Consulate in Thailand (USE-THA). The Mekong - U.S. Partnership Heroes Series: Building a Bright Future for the Mekong. Available at: https://th.usembassy.gov/the-mekong-u-s-partnership-heroes-series-building-a-bright-futurefor-the-mekong/, 2021.

U.S. Embassy in Cambodia (USE-CAM). The Mekong-U.S. Partnership and the Friends of the Mekong: Proven Partners for

1045 the Mekong Region. Available at: https://kh.usembassy.gov/the-mekong-u-s-partnership-and-the-friends-of-the-mekongproven-partners-for-the-mekong-region/, 2021.

U.S. Mission to ASEAN (USM-ASEAN). Secretary Pompeo to Participate in Virtual U.S.-ASEAN, EAS, ARF, MekongU.S. Partnership Foreign Ministers Meeting September 9-11. Available at: https://asean.usmission.gov/secretary-pompeo-toparticipate-in-virtual-u-s-asean-eas-arf-mekong-u-s-partnership-foreign-ministers-meetings-september-9-11/, 2020.

1050 Vaccari, C., Cadwick, A. Deepfakes and Disinformation: Exploring the Impact of Synthetic Political Video on Deception, Uncertainty, and Trust in News. Social Media + Society 6(1): 1-13, doi 10.1177/2056305120903408, 2020.

Vaikl, C. Predatory Journals. Authors and readers beware. Canadian Family Physician Medecin de Famille Canadien 65(2): 92-94, 2019.

van Laar, J. A. Pragmatic Inconsistency and Credibility. Argumentation 21(1): 317-334, doi 10.1007/s10503-007-9049-8, 10552007.

Van, H. Chinese dams withhold water, worsen 2019 drought in Mekong Delta: researchers. Tuo Tre News. Available at: https:/tuoitrenews.vn/news/society/20200530/chinese-dams-withhold-water-worsen-2019-drought-in-mekong-deltaresearchers/54823.html, 2020.

Wade, J. Duelling experts in mediation and negotiation: How to respond when eager expensive entrenched expert egos escalate enmity. Conflict Resolution Quarterly 21(4): 419-436, doi 10.1002/crq.71, 2004. 
https://doi.org/10.5194/hess-2021-647

Preprint. Discussion started: 18 January 2022

(c) Author(s) 2022. CC BY 4.0 License.
Hydrology and

Earth System

Sciences

Discussions

Wang, W., Lu, H., Leung, L. R., Li, H. Y., Zhao, J., Tian, F., Yang, K., Sothea, K. Dam Construction in Lancang-Mekong River Basin Could Mitigate Future Flood Risk From Warming-Induced Intensified Rainfall. Geoscience Research Letters 44(1): 10378-10386, doi: 10.1002/2017GL075037, 2017.

Weber, E.P., Khademian, A.M. Wicked problems, knowledge, challenges, and collaborative capacity builders in network settings. Public Administration Review 68(2): 333-349, doi 10.1111/j.1540-6210.2007.00866.x, 2008.

Weber, E.P., Memon, A., Painter B. Science, Society and Water Resources in New Zealand: Recognizing and Overcoming a Societal Impasse. Journal of Environmental Policy \& Planning 13(1): 46-69, doi 10.1080/1523908X.2011.564414, 2011.

Wei, J., Ghoreishi, M., Souza, F., Lu, Y., Tian, F. A Sociohydrological Framework to Understand Conflict and Cooperation Dynamics in Transboundary Rivers. Presented at EGU General Assembly, Online, 4-8 May, 2020.

1070 Wei, J., Wei, J., Tian, F., Nott, N., de Witt, C., Guo, L., Lu, Y. News media coverage of conflict and cooperation dynamics of water events in the Lancang-Mekong River basin. Hydrology and Earth System Sciences 25(3): 1603-1615, doi 10.5194/hess25-1603-2021, 2021.

Weible, C.M. Expert-based information and policy subsystems: A review and synthesis. Policy Studies Journal 36(4): 615635, doi 10.1111/j.1541-0072.2008.00287.x, 2008.

1075 Weingart, P. The moment of truth for science. EMBO reports 3(8): 703-706, doi 10.1093/embo-reports/kvf165, 2002.

Weng, Y., CH. Contrasting visions of science in ecological restoration: Expert-lay dynamics between professional practitioners and volunteers. Geoforum 65(1): 134-145, 2015.

Werner, R. The focus on bibliometrics makes papers less useful. Nature, 517, 245-245, doi 10.1038/517245a, 2015.

Wester, P., Rap, E., Vargas, V. The hydraulic mission and the Mexican hydrocracy: Regulation and reforming the flows of 1080 water and power. Water Alternatives 2(3): 395-415, 2009.

Xinhua. Full text of Vientiane Declaration of the Third Mekong-Lancang Cooperation (LMC) Leaders' Meeting. Available at: http://www.xinhuanet.com/english/2020-08/24/c_139314536.htm, 2020.

Young, J.C., Waylen, K.A., Sarkii, S., Albon, S., Bainbridge, I., Balian, E., Davidson, J., Edwards, D., Fairley, R., Margerison, C., McCracken, D., Owen, R., Quine, C.P., Stewart-Roper, C., Tompson, D., Tinch, R., Hove, S.V., Watt, A. Improving the

1085 science-policy dialogue to meet the challenges of biodiversity conservation: having conversations rather than talking at oneanother. Biodiversity and Conservation 23(1): 387-404, doi 10.1007/s10531-013-0607-0, 2014.

Yu, D.J., Chang, J., Davis, T.T., Hillis, V., Marston, L., Oh, W.S., Sivapalan, M., Waring, T.M. Socio-hydrology: an interplay of design and self-organization in a multilevel world. Ecology and Society 25(4): 1-16, doi 10.5751/ES-11887-250422, 2020. Zeitoun, M. Cascão, A. E., Warner, J., Mirumachi, N., Matthews, N., Menga, F., Farnum, R. Transboundary water interaction III: Contest and compliance. International Environmental Agreements: Politics, Law and Economics 17(2): 271294, doi: 10.1007/s10784-016-9325-x, 2017.

Zeitoun, M., Mirumachi, N. Transboundary water interaction I: reconsidering conflict and cooperation. International Environmental Agreements: Policies, Law and Economics 8(1): 297-316. doi: 10.1007/s10784-008-9083-5, 2008. 
https://doi.org/10.5194/hess-2021-647

Preprint. Discussion started: 18 January 2022

(c) Author(s) 2022. CC BY 4.0 License.

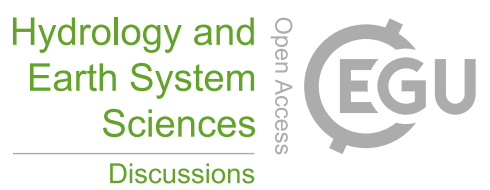

Zhang, Y., Hao, Z., Xu, C. Y., Lai, X. Response of melt water and rainfall runoff to climate change and their roles in controlling 1095 streamflow changes of the two upstream basins over the Tibetan Plateau. Hydrology Research 51(2): 272-289, doi: 10.2166/nh.2019.075, 2020.

Zhong, Y., Tian, F., Hu, H., Grey, D., Gilmont, M. Rivers and reciprocity: Perceptions and policy on international watercourses. Water Policy 18(4): 803-825, doi: 10.2166/wp.2016.229, 2016.

Zhou, X., Zafarani, R. A Survey of Fake News: Fundamental Theories, Detection Methods, and Opportunities. ACM 1100 Computing Surveys 53(5): 1-37, doi 10.1145/3395046, 2020. 